\title{
‡USGS
}

science for a changing world

\section{Groundwater Chemistry in the Vicinity of the Puna Geothermal Venture Power Plant, Hawai'i, After Two Decades of Production}

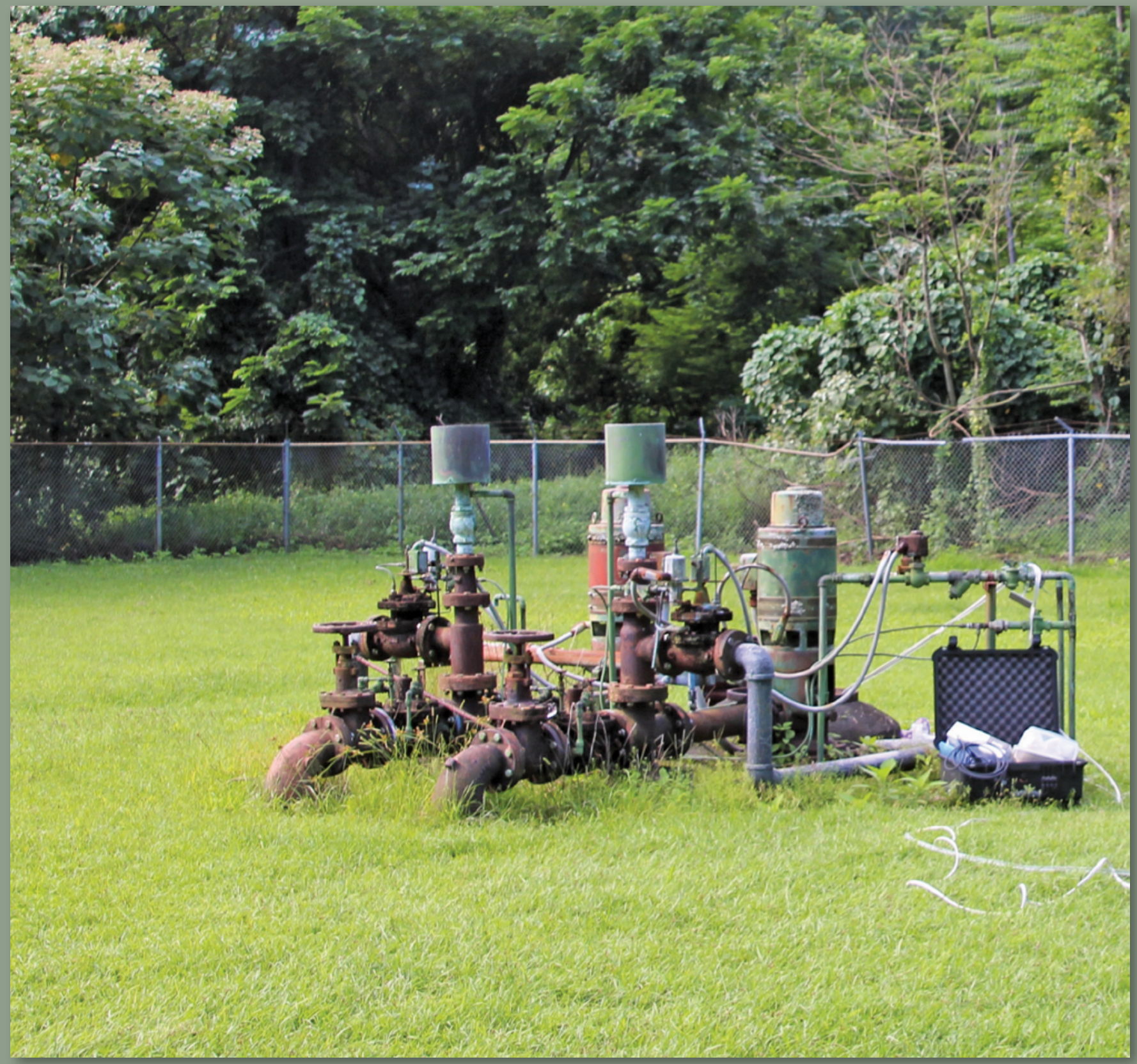

Scientific Investigations Report 2015-5139 


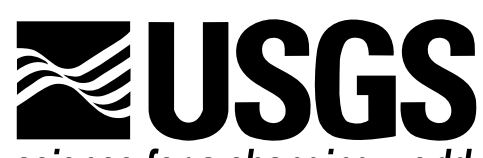

science for a changing world

\section{Groundwater Chemistry in the Vicinity of the Puna Geothermal Venture Power Plant, Hawai'i, After Two Decades of Production}

By W.C. Evans, D. Bergfeld, A.J. Sutton, R.C. Lee, and T.D. Lorenson

Scientific Investigations Report 2015-5139 


\section{U.S. Department of the Interior SALLY JEWELL, Secretary}

\section{U.S. Geological Survey Suzette M. Kimball, Acting Director}

\section{U.S. Geological Survey, Reston, Virginia: 2015}

For more information on the USGS - the Federal source for science about the Earth, its natural and living resources, natural hazards, and the environment-visit http://www.usgs.gov/ or call 1-888-ASK-USGS (1-888-275-8747).

For an overview of USGS information products, including maps, imagery, and publications, visit http://www.usgs.gov/pubprod/.

Any use of trade, firm, or product names is for descriptive purposes only and does not imply endorsement by the U.S. Government.

Although this information product, for the most part, is in the public domain, it also may contain copyrighted materials as noted in the text. Permission to reproduce copyrighted items must be secured from the copyright owner.

Suggested citation:

Evans, W.C., Bergfeld, D., Sutton, A.J., Lee, R.C., and Lorenson, T.D., 2015, Groundwater chemistry in the vicinity of the Puna Geothermal Venture power plant, Hawai'i, after two decades of production: U.S. Geological Survey Scientific Investigations Report 2015-5139, 26 p., http://dx.doi.org/10.3133/sir20155139. 


\section{Contents}

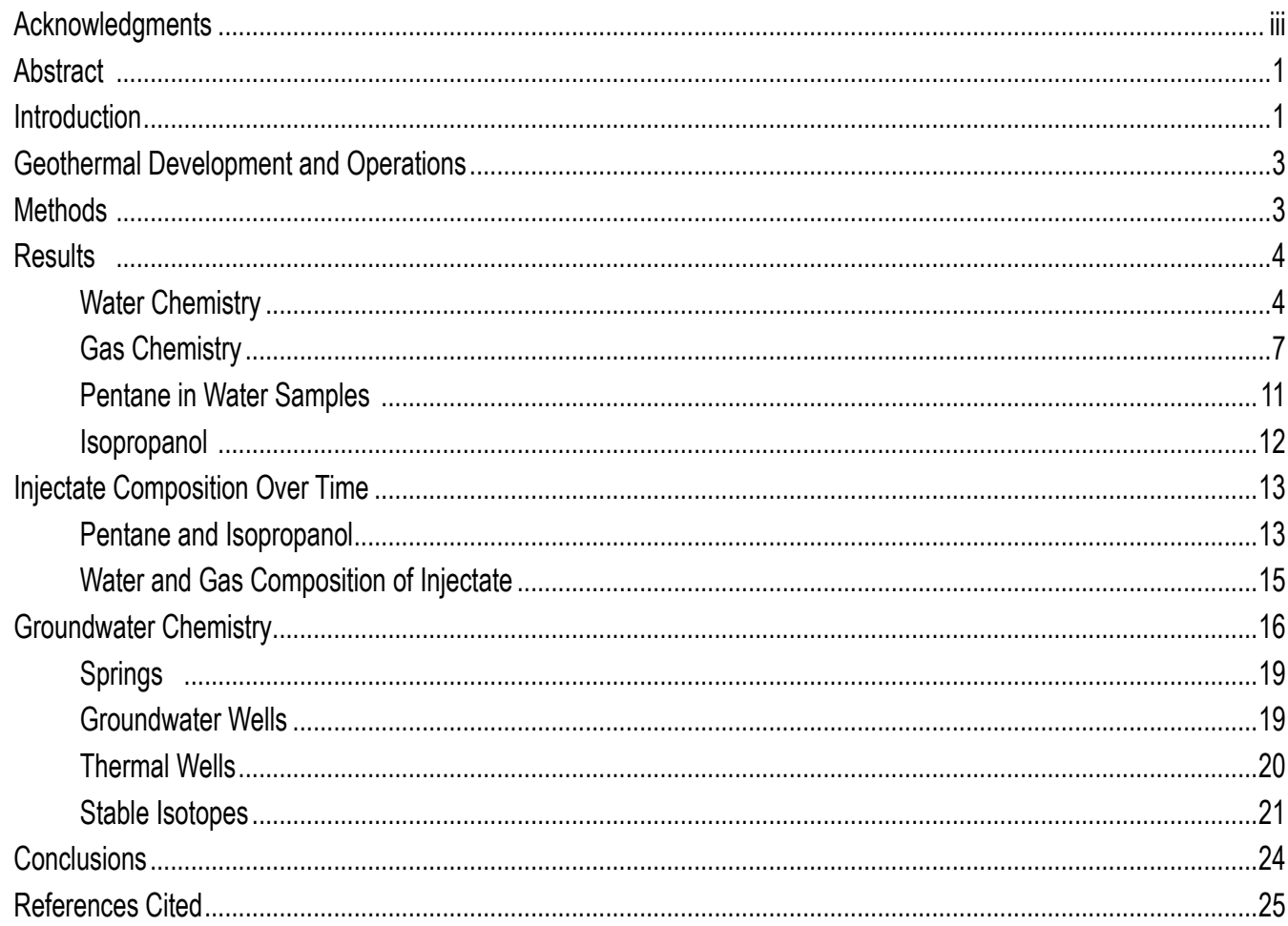

\section{Figures}

1. Map of study area showing sample locations and features of interest .......................................................

2. Concentration of alkane hydrocarbons in gas samples from the steam and injectate pipelines

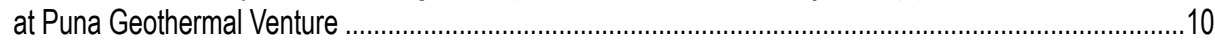

3. Concentration of alkane hydrocarbons in both wells where pentane was detected, MW-2 and Keonepoko

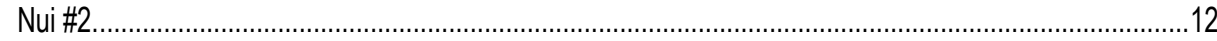

4. Concentration of pentane in the noncondensable gas line at Puna Geothermal Venture, as reported in Hawai' i State Department of Health records for 2001, 2004, and 2007-14 .......................................13

5. Concentration of $\mathrm{Na}_{\text {and }} \mathrm{SO}_{4}$ versus $\mathrm{Cl}$ in injectate over time, based on Hawai'i State Department of

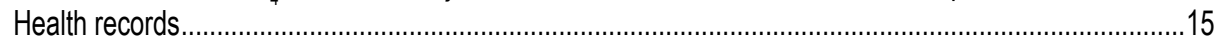

6. Concentration of several major chemical species in the injectate over time, based on Hawai'i State

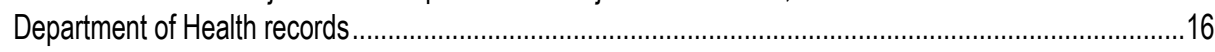

7. Concentration of gas species in the noncondensable gas line over time, based on Hawai'i State Department of Health records for 1995, 1998, 2000, 2001, 2004, and 2007-14..................................16

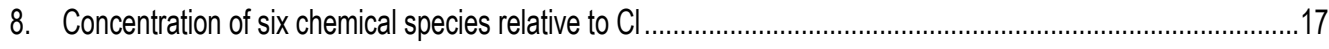

9. Expanded view of figure 8 highlighting results from particular wells ............................................................18

10. Temperature and concentration of several major species in MW-2 over time based on Hawai'i State

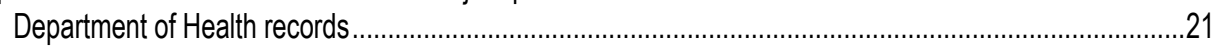

11. Data for thermal groundwater wells added to data of figure 8, concentrations of selected chemical

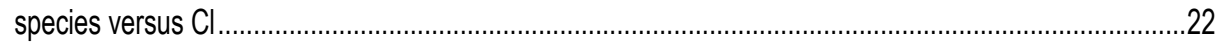

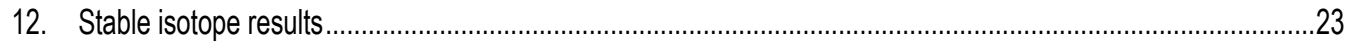




\section{Tables}

1. Location and type of features sampled and results of on-site measurements .........................5

2. Concentrations of major and minor dissolved species in milligrams per liter .......................... 6

3. Concentrations of trace metals, $\mathrm{NH}_{3^{\prime}}$ and $\mathrm{H}_{2} \mathrm{~S}$, in milligrams per liter, and stable isotopes of water, in per mil......

4. Composition (in volume percent) of gas bubbles in samples collected from the Puna Geothermal Venture steam and injectate lines.

5. Concentrations of dissolved hydrocarbons in micromoles per kilogram for all samples containing a hydrocarbon larger than methane.

6. Volatile organic compounds measured in water samples

\section{Conversion Factors}

International System of Units to Inch/Pound

\begin{tabular}{lcl}
\hline \multicolumn{1}{c}{ Multiply } & By & \multicolumn{1}{c}{ To obtain } \\
\hline meter $(\mathrm{m})$ & 3.281 & foot $(\mathrm{ft})$ \\
kilometer $(\mathrm{km})$ & 0.6214 & mile $(\mathrm{mi})$ \\
\hline \multicolumn{3}{c}{ Volume } \\
\hline liter $(\mathrm{L})$ & 0.2642 & gallon $(\mathrm{gal})$ \\
\hline \multicolumn{3}{c}{ Flow rate } \\
\hline meter per day $(\mathrm{m} / \mathrm{d})$ & 3.281 & foot per day $(\mathrm{ft} / \mathrm{d})$ \\
\hline \multicolumn{3}{c}{ Mass } \\
\hline gram $(\mathrm{g})$ & 0.03527 & ounce, avoirdupois $(\mathrm{oz})$ \\
kilogram $(\mathrm{kg})$ & 2.205 & pound, avoirdupois $(\mathrm{lb})$ \\
\hline
\end{tabular}

Temperature in degrees Celsius $\left({ }^{\circ} \mathrm{C}\right)$ may be converted to degrees Fahrenheit $\left({ }^{\circ} \mathrm{F}\right)$ as ${ }^{\circ} \mathrm{F}=\left(1.8 \times{ }^{\circ} \mathrm{C}\right)+32$.

Temperature in degrees Fahrenheit $\left({ }^{\circ} \mathrm{F}\right)$ may be converted to degrees Celsius $\left({ }^{\circ} \mathrm{C}\right)$ as ${ }^{\circ} \mathrm{C}=\left({ }^{\circ} \mathrm{F}-32\right) / 1.8$.

\section{Datum}

- Vertical coordinate information is referenced to the North American Vertical Datum of 1983 (NAD83).

- Horizontal coordinate information is referenced to the North American Vertical Datum of 1983 (NAD83).

- Altitude, as used in this report, refers to distance above the vertical datum.

\section{Supplemental Information}

- Specific conductance is given in microsiemens per centimeter at 25 degrees Celsius $\left(\mu \mathrm{S} / \mathrm{cm}\right.$ at $\left.25^{\circ} \mathrm{C}\right)$.

- Concentrations of chemical constituents in water are given in either milligrams per liter $(\mathrm{mg} / \mathrm{L})$, micrograms per liter $(\mu \mathrm{g} / \mathrm{L})$, or micromoles per kilogram $(\mu \mathrm{mol} / \mathrm{kg})$, where a kilogram of water is nearly equal to a liter.

- Concentrations of chemical constituents in gas are given in either volume percent or in parts-per-million by volume.

- Results for measurements of stable isotopes of water are expressed as the relative difference in parts per thousand (per mil) in the ratio of the number of the less abundant isotope $\left(\mathrm{D}\right.$ or $\left.{ }^{18} \mathrm{O}\right)$ to the number of the more abundant isotope $\left(\mathrm{H}\right.$ or $\left.{ }^{16} \mathrm{O}\right)$ with respect to Vienna Standard Mean Ocean Water (VSMOW). 


\section{Acknowledgments}

Jim Kauahikaua (former U.S. Geological Survey [USGS] Scientist-In-Charge of the Hawaiian Volcano Observatory) encouraged us to undertake this study. Jeff Melrose (consultant for the County of Hawai'i) was influential in moving the study forward and in arranging logistics. Kawika Uyehara and Keith Okamoto (County Department of Water Supply [DWS]) helped arrange sample collection at public-supply wells, including the Kapoho Shaft, and provided the DWS records of water chemistry. Mark Prescott and Sam Martoni arranged sample collection at the private wells. Mike Kaleikini (Ormat) provided helpful information about the Puna Geothermal Venture plant, fluid flowpaths, additives used, and spreadsheets of monitoring data, and also arranged for our sample collection at the plant, which relied heavily on assistance from Gary Dahl (Ormat). Bob Whittier (Hawai'i State Department of Health $[\mathrm{HDOH}]$, Safe Drinking Water Branch) provided a huge amount of background information on past and present monitoring programs; Norris Uehara and staff in that office patiently scanned hundreds of HDOH analytical records and sent them as pdf files. Don Thomas (University of Hawai'i) and Thomas Travis provided helpful feedback on the study objectives, as did Steve Gingerich and Jennifer Lewicki (USGS). Mark Huebner (USGS) transcribed hard-copy data into electronic spreadsheets and conducted the anion analyses. Steve Ingebritsen (USGS) and Don Thomas (University of Hawai'i) provided helpful reviews of the draft report. 



\title{
Groundwater Chemistry in the Vicinity of the Puna Geothermal Venture Power Plant, Hawai'i, After Two Decades of Production
}

\author{
By W.C. Evans, D. Bergfeld, A.J. Sutton, R.C. Lee, and T.D. Lorenson
}

\begin{abstract}
We report chemical data for selected shallow wells and coastal springs that were sampled in 2014 to determine whether geothermal power production in the Puna area over the past two decades has affected the characteristics of regional groundwater. The samples were analyzed for major and minor chemical species, trace metals of environmental concern, stable isotopes of water, and two organic compounds (pentane and isopropanol) that are injected into the deep geothermal reservoir at the power plant. Isopropanol was not detected in any of the groundwaters; confirmed detection of pentane was restricted to one monitoring well near the power plant at a low concentration not indicative of source. Thus, neither organic compound linked geothermal operations to groundwater contamination, though chemical stability and transport velocity questions exist for both tracers. Based on our chemical analysis of geothermal fluid at the power plant and on many similar results from commercially analyzed samples, we could not show that geothermal constituents in the groundwaters we sampled came from the commercially developed reservoir. Our data are consistent with a long-held view that heat moves by conduction from the geothermal reservoir into shallow groundwaters through a zone of low permeability rock that blocks passage of geothermal water. The data do not rule out all impacts of geothermal production on groundwater. Removal of heat during production, for example, may be responsible for minor changes that have occurred in some groundwater over time, such as the decline in temperature of one monitoring well near the power plant. Such indirect impacts are much harder to assess, but point out the need for an ongoing groundwater monitoring program that should include the coastal springs down-gradient from the power plant.
\end{abstract}

\section{Introduction}

The lower East Rift Zone (LERZ) of Kīlauea volcano on the island of Hawai' $i$ (fig. 1) hosts a geothermal reservoir at depths near $2 \mathrm{~km}$, and the hot fluids have been exploited for power generation since 1981 (Thomas, 1990). An early and on-going concern about geothermal development is the potential impact on local groundwater (for example, Iovenitti, 1990). To address this concern, a major scientific effort was carried out in the early days of well drilling and development to characterize existing hydrologic conditions in the region and delineate potential vulnerabilities (Iovenitti, 1990; Ingebritsen and Scholl, 1993; Sorey and Colvard, 1994; Janik and others, 1994; Gingerich, 1995; Scholl and others, 1995). The basaltic lava flows from Kîlauea and its rift zone vents provide highly permeable flow paths for groundwater, but vertical dikes within the upper rift zone constitute effective barriers. Thus, groundwater north of the rift zone flows northeast toward the ocean. Groundwater within the rift zone flows generally down rift toward Cape Kumukahi, but some outflow into the permeable lava flows to the south is suspected along the lower part of the rift where the concentration of impermeable dikes decreases (Takasaki, 1993; Gingerich, 1995). Several shallow groundwater wells in the LERZ are tens of degrees warmer than ambient temperatures, and brackish springs along the southeast coast of the island, down the hydraulic gradient from the LERZ, are several degrees warmer than background. Thus, some type of hydrologic connection between the geothermal and groundwater systems is indicated. On the other hand, the warm groundwaters lack some of the distinctive features in the chemical composition of the deep geothermal water. This fact and other information from drill cores and temperature profiles in deep wells led many investigators to conclude that direct leakage of water from the geothermal reservoir into groundwater was insignificant (Janik and others, 1994; Sorey and Colvard, 1994). The warm temperatures in groundwater wells and coastal springs were commonly attributed to conductive heat transfer. Although some direct leakage of reservoir steam and sulfur-rich gas was proposed to account for the elevated temperatures and sulfate concentrations in shallow monitoring wells in the LERZ (Janik and others, 1994; Sorey and Colvard, 1994), a discharge pathway for hot water from the reservoir was not identified.

The large-scale scientific investigations of the hydrogeology and groundwater chemistry at Kîlauea and the 
LERZ in the early 1990s established the baseline geochemical conditions at about the time that Puna Geothermal Venture (PGV) began producing power from new wells in place of the original HGP-A well that had been used throughout most of the 1980s. A follow-up monitoring program was recommended (Sorey and Colvard, 1994) for detection of any impacts from producing the hot reservoir fluids or from injecting the cooled water back into the deep reservoir. As a condition of the underground injection control permit (UH1529), PGV must conduct a hydrologic monitoring program. Under this program, several shallow wells, thermal and nonthermal, were sampled quarterly for chemical analysis, and the results reported to the State of Hawai' $i$ Department of Health (HDOH) from 1991 through 2000. Beginning in 2001, the number of wells sampled each round by PGV was reduced to two thermal wells near the power plant, MW-2 and either MW-1 or MW-3, which are adjacent wells that tap similar depths. The County of Hawai' $i$ Department of Water Supply (DWS) routinely monitors nonthermal wells that are used for public supply. Coastal springs have gone largely unmonitored, and thus the full, cumulative impact of over 20 years of geothermal production/injection on this large groundwater system is unknown. These springs, sometimes referred to as anchialine pools, are brackish and unsuitable for drinking or agricultural use, but are recognized as important habitats in the near-shore environment (Foote, 2005). Recently (September
2013), a local public health assessment study group headed by Dr. Peter S. Adler recommended that the County commission a study to re-evaluate the effects of geothermal operations on local groundwater and the near-ocean environment (Adler, 2013). Our study was proposed in response to a County of Hawai'i request.

The work was planned to be a pilot study of fairly limited scope: collect enough samples to obtain representative coverage of the various types of groundwater (for example, deep geothermal water, warm saline spring water, publicsupply water) rather than attempt to sample every available feature. The results could then be used to help determine the need for a bigger, more comprehensive study. None of the water-supply wells currently in use are obviously downgradient from the PGV plant, but some have static water levels at lower elevations than those reported for the geothermal wells. Thus, sample coverage extended nearly $10 \mathrm{~km}$ away from PGV to help detect any impact of development. Some of the intended target wells down-gradient from PGV were found unsuitable for sampling because of access issues or nonfunctional pumps. Thus more emphasis was placed on sampling the coastal springs to characterize ground-water most likely to be impacted by geothermal operations.

Sites sampled in April-May 2014 included a pair of public supply wells on either side of the LERZ, three private water-supply wells north of the LERZ, six coastal springs
Figure 1. Map of study area showing sample locations and features of interest. Sample numbers simplified from table 1 (for example, PG14-01 is 1). Coastal springs and ponds are shown as stars, and wells are shown as circles (in red for the production/injection wells at Puna Geothermal Venture). The lower East Rift Zone (LERZ) of Kīlauea volcano lies between the dashed lines (after Janik and others, 1994).

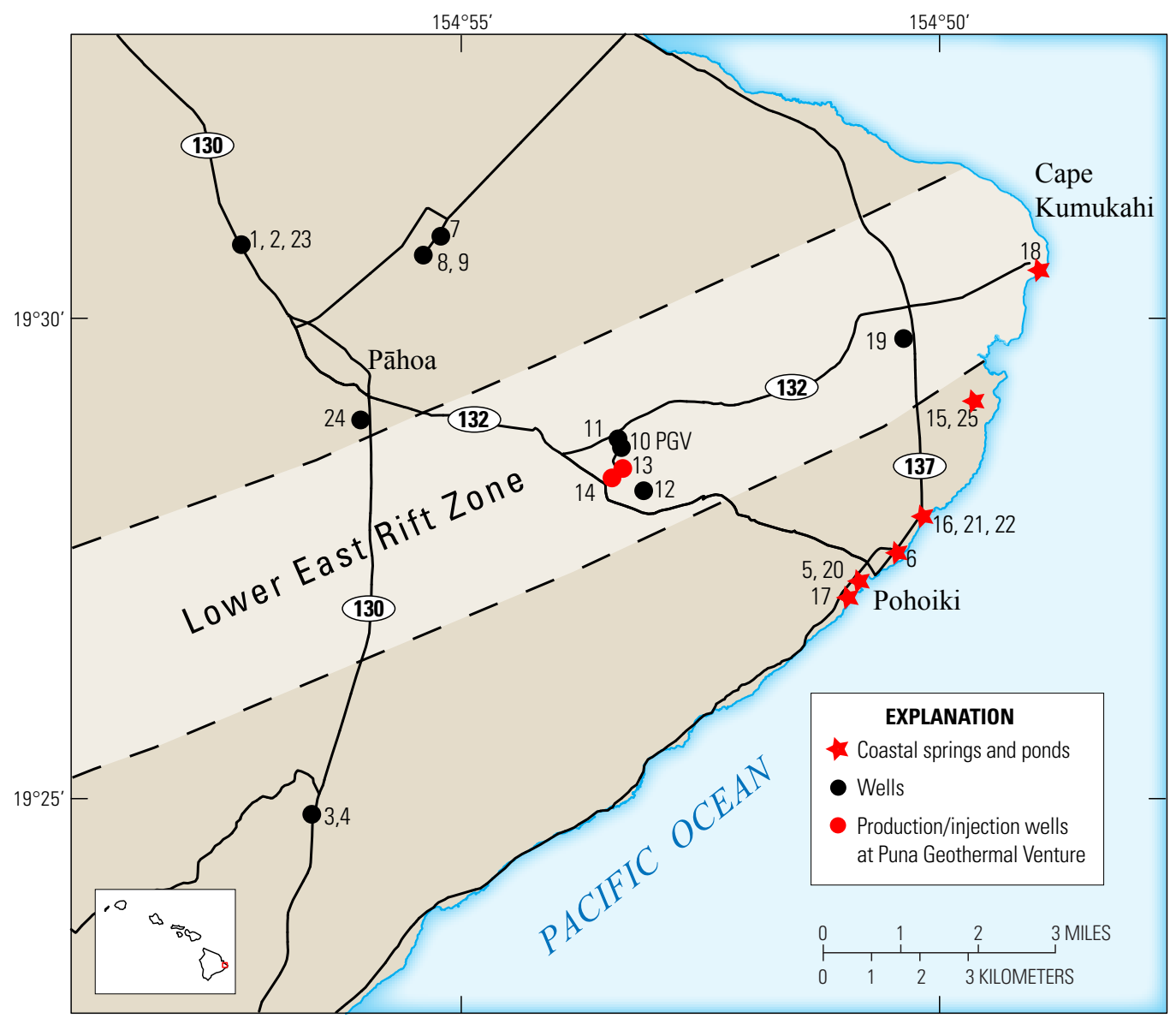


and pools, and the three warm monitoring wells near the power plant. The steam and residual brine from a geothermal production well (KS-5), and the combined injectate stream (at Pad A) were also sampled. Additional samples were collected in December 2014 from two public supply wells (one unused) within or adjacent to the LERZ, and four coastal springs, two of which had been sampled previously in April-May 2014. One of the public supply wells north of the LERZ was also resampled. The water samples were analyzed for a suite of inorganic constituents including several heavy metals, but a unique feature of our study was the high sensitivity analysis of pentane and isopropanol. These two organic compounds are added to the injectate stream within the power plant and could serve as definitive tracers of the geothermal fluid. Although degradation of natural organic matter in any aquifer can release a wide range of organic compounds into groundwater, especially at elevated temperatures, neither pentane nor isopropanol should be present at more than trace levels in groundwaters that are uncontaminated by PGV injectate. Current groundwater monitoring protocol does not include analysis of these compounds.

This report presents chemical analyses of the samples discussed above. Selected chemical data gathered during the past $\sim 20$ years of monitoring conducted or overseen by the $\mathrm{HDOH}$ and DWS are also presented, and the combined dataset is evaluated to assess the likelihood that geothermal development is affecting the regional groundwater.

\section{Geothermal Development and Operations}

Exploratory drilling in the 1960s established the existence of hot water within the LERZ to the south and east of the community of Pāhoa (Thomas, 1987). The first productive well (HGP-A) was completed in 1976 to a depth of nearly $2 \mathrm{~km}$. After a series of tests, this well was used for power production beginning in 1981 and ending in 1989 (Thomas, 1987, 1990). During the 1980s and early 1990s, PGV or its predecessor companies drilled the nearby Kapoho State wells (KS series), some reaching depths in excess of $2.5 \mathrm{~km}$, and began producing power in May 1993 (Sorey and Colvard, 1994). The PGV plant has been in operation since that time and has continued well drilling operations; for example, KS-13 in 2005 (Teplow and others, 2009)

Unlike the HGP-A installation, the PGV plant does not use infiltration ponds for liquids or engineered abatement for the produced gases under normal conditions, though abatement of $\mathrm{H}_{2} \mathrm{~S}$ is carried out during emergencies that cause steam release to the atmosphere. The plant does incorporate a steam flash process where steam and gases separate from the residual boiled water (brine). The high-pressure steam drives a turbine in the generating system, but condensation of the steam takes place downstream in a heat exchanger where the heat is used to boil liquid pentane. The condensed steam, and ultimately the noncondensable gases such as $\mathrm{CO}_{2}, \mathrm{H}_{2}, \mathrm{~N}_{2}$, and $\mathrm{H}_{2} \mathrm{~S}$, are mixed back into the brine flow, and the recombined fluid is injected in its entirety back into the deep geothermal reservoir. The pentane vapor from the heat exchanger drives an additional turbine, is condensed back to liquid, and is ultimately returned to the heat exchanger. Thus, according to plant design, no geothermal gases or fluids are intentionally released to the environment, and the pentane circulates through the plant in a closed loop that is separate from the water and steam. In practice, a small amount of pentane does enter the flow stream and is injected into the reservoir.

Because steam and gas separate from the residual brine upstream from the sampling ports, both the steam and brine pipelines were sampled in order to completely characterize the reservoir fluid tapped by the plant. Our sample from the injectate pipeline was collected downstream from the point where steam, gas, and brine are recombined and just prior to the point of injection back into the reservoir. The injectate sample is particularly important to this study because it contains all the gases and dissolved species that are present in the produced reservoir fluid. It would also contain any additives (for example, isopropanol) and other compounds derived from plant operations that enter the flow system. Geothermal water that enters the local groundwater system, either through permeable flowpaths out of the reservoir or through leaks in the well casings, would most likely resemble the injectate in terms of chemistry. Distinguishing the composition of the injectate from that of other thermal fluid(s) long known to be present in the warm groundwaters and coastal springs is an important part of evaluating connectivity between the developed geothermal system and groundwater, a key step in assessing impact.

\section{Methods}

The location of each sampled feature was determined to within a few meters with a hand-held global positioning system (GPS). Water temperature, specific conductance, $\mathrm{pH}$, and dissolved oxygen (DO) were measured on-site using handheld meters. At springs, the measurements were made near the water surface. For wells, a continuous flow of pumped water from the wellhead was directed into a plastic container housing the measuring probes. In all cases, the $\mathrm{pH}$ meter was calibrated with buffer solutions at the temperature of the water.

Water samples were collected using standard methods that have been described in detail elsewhere (Bergfeld and others, 2013). Briefly, water collected for chemical analysis was filtered on-site into plastic bottles using a plastic syringe and 0.45 -micrometer $(\mu \mathrm{m})$ filters. The bottle for cation analysis was acidified to $\mathrm{pH} 2$ with nitric acid. Glass bottles were filled with unfiltered water for alkalinity determinations, and analysis of stable isotopes of hydrogen and oxygen. Water was collected for pentane analysis by two different methods. In one method, water was drawn up into a 140-cubic centimeter (cc) syringe and injected into a pre-evacuated glass bottle (DIC bottle) 
Groundwater Chemistry in the Vicinity of the Puna Geothermal Venture Power Plant, Hawai'i

through a septum port, leaving a headspace volume of about $15-25 \mathrm{cc}$ in the bottle. A description of these bottles is provided in Evans and others (2002). The second method made use of 200-cc serum bottles, which were filled from the bottom by flowing in water through flexible tubing. After allowing $600 \mathrm{cc}$ of water to overflow and flush the bottle, the tubing was slowly withdrawn and a rubber septum was inserted into the top of the bottle and crimped in place with a metal band. Samples for isopropanol analysis were collected in triplicate into 40-cc amber glass bottles fitted with screw-on septa caps. Bottles were filled to exclude any bubbles as described in Wilde and others (2004). Isopropanol samples were refrigerated or stored on ice between collection and analysis.

Sampling of geothermal fluids from the pipelines requires precooling to prevent extensive loss of steam and gas as the hot fluids are depressurized. Cooling was accomplished at the PGV plant by collecting the samples through a cooling jacket flushed by a steady stream of cold water, that resulted in collection temperatures of about $30^{\circ} \mathrm{C}$. Gas solubility increases as temperature decreases, and for sampling the brine pipeline, this level of cooling was sufficient to produce a flow of bubble-free water at the collection point. Bubble-free water was initially obtained from the injectate pipeline but could not be maintained throughout sampling due to the added gases in the injectate. The small bubbles that formed in the sampling line were captured into an inverted funnel and collected in a pre-evacuated glass bulb. As anticipated, the steam line was so gas rich that the water flow contained a steady stream of bubbles that were also collected into a glass bulb. Two other special sampling procedures (Presser and Barnes, 1974) were used on the geothermal fluids: water filtered into glass bottles was preserved for $\mathrm{H}_{2} \mathrm{~S}$ analysis with zinc acetate and sodium hydroxide, and aliquots of the brine and injectate were fielddiluted with deionized water to prevent polymerization of silica prior to analysis.

Samples collected for alkalinity and $\mathrm{H}_{2} \mathrm{~S}$ were titrated at the end of each sampling day. Standardized solutions of $\mathrm{H}_{2} \mathrm{SO}_{4}$ (for alkalinity) and $\mathrm{Na}_{2} \mathrm{~S}_{2} \mathrm{O}_{3}$ (for total sulfide) were used following the electrometric and iodometric procedures, respectively, described in Presser and Barnes (1974). Other water samples and gases were analyzed at several U.S. Geological Survey (USGS) laboratories. Chemical analyses were conducted at USGS in Menlo Park, Calif. Gas samples from the PGV plant were analyzed on gas chromatographs in two different USGS labs following published methods for free gases (Evans and others, 1981) and headspace gases (Bergfeld and others, 2011). One gas chromatograph was equipped with a thermal conductivity detector (TCD) responsive to all gas species; the other had an additional flame ionization detector (FID), highly sensitive but only responsive to flammable gas species, in this case, hydrocarbons. Water samples were analyzed for anions by ion chromatography and for cations by argon plasma optical emission spectrometry. Stable isotope analyses of the waters were performed by mass spectrometry at the USGS Reston Stable Isotope Laboratory (Revesz and Coplen, 2008a,b). Isopropanol analyses were conducted at the USGS National Water Quality
Laboratory in Denver Colo. using a volatile organic compound (VOC) heated purge and trap method on Schedule 4437 that detects 37 other VOCs. The VOC analysis was performed on samples from PG14-01 to PG14-19 and PG14-24.

Dissolved pentane samples were also analyzed at two different USGS labs in Menlo Park, Calif. Pentane samples collected in DIC tubes were analyzed on a gas chromatograph equipped with both a TCD and a FID using a slight modification of the headspace gas method of Bergfeld and others (2011). This method yields results for a large suite of nonhydrocarbon and hydrocarbon gas species, including pentane. The gas in the equilibrated headspace was expanded to a pre-evacuated inlet system and injected into the gas chromatograph. From the known volumes of the headspace and inlet system, and the measured injection pressure, the concentrations of the gases that were originally dissolved in the water sample can be calculated from their individual Henry law solubilities (Wilhelm and others, 1977; Chapoy and others, 2008). Samples collected in serum bottles were analyzed by equilibrating $100 \mathrm{cc}$ of water with $40 \mathrm{cc}$ of helium and injecting the equilibrated gas into a gas chromatograph equipped with an FID. This method, adapted from McAuliffe (1971), has excellent sensitivity for many alkanes including pentane.

\section{Results}

\section{Water Chemistry}

Sampled features are listed in table 1 with GPS locations and results of measurements made at the time of sampling. Many of these features were also sampled in the early 1990s by Janik and others (1994), who included chemical analyses from even earlier studies in their data tables. For features listed in Janik and others (1994), the ID number used by those authors, the number of analyses they report, and the years spanned by those analyses are given. Specific conductance increases with ionic strength and is a qualitative measure of salinity. Water supply wells all have values below 1,200 microsiemens per centimeter $(\mathrm{mS} / \mathrm{cm})$; coastal springs and geothermal fluids have much higher values due to the greater influence of seawater, which for reference has a specific conductance of about $50,000 \mathrm{mS} / \mathrm{cm}$. Dissolved oxygen in active water supply wells is at or near concentrations expected for local rainwater, showing that dissolved oxygen is largely conserved in the shallow groundwater from recharge to withdrawal. Dissolved oxygen is somewhat depleted in warm waters, such as the monitoring wells and most springs. The PGV fluids were all expected to be oxygen-free; the tiny amounts of dissolved oxygen detected may reflect the fact that air could not be completely excluded from the container housing the $\mathrm{pH}$ and oxygen probes. Note that the temperature reported for well samples is that of the water in the collection container, not actual down-hole temperature. 
Table 1. Location and type of features sampled and results of on-site measurements. Last 4 columns give the site ID number used in Janik and others (1994), the number of samples they report for each site, and the years spanned by those samples.

[SW, supply well; MW, monitoring well; IW, injection well; PW, production well; $\mathrm{B}$, brine pipeline; $\mathrm{S}$, steam pipeline; ${ }^{\circ} \mathrm{C}$, degrees Celsius; $\mu \mathrm{S} / \mathrm{cm}$, microsiemens per centimeter at 25 degrees Celsius; DO, dissolved oxygen; mg/L, milligrams per liter; nm, not measured]

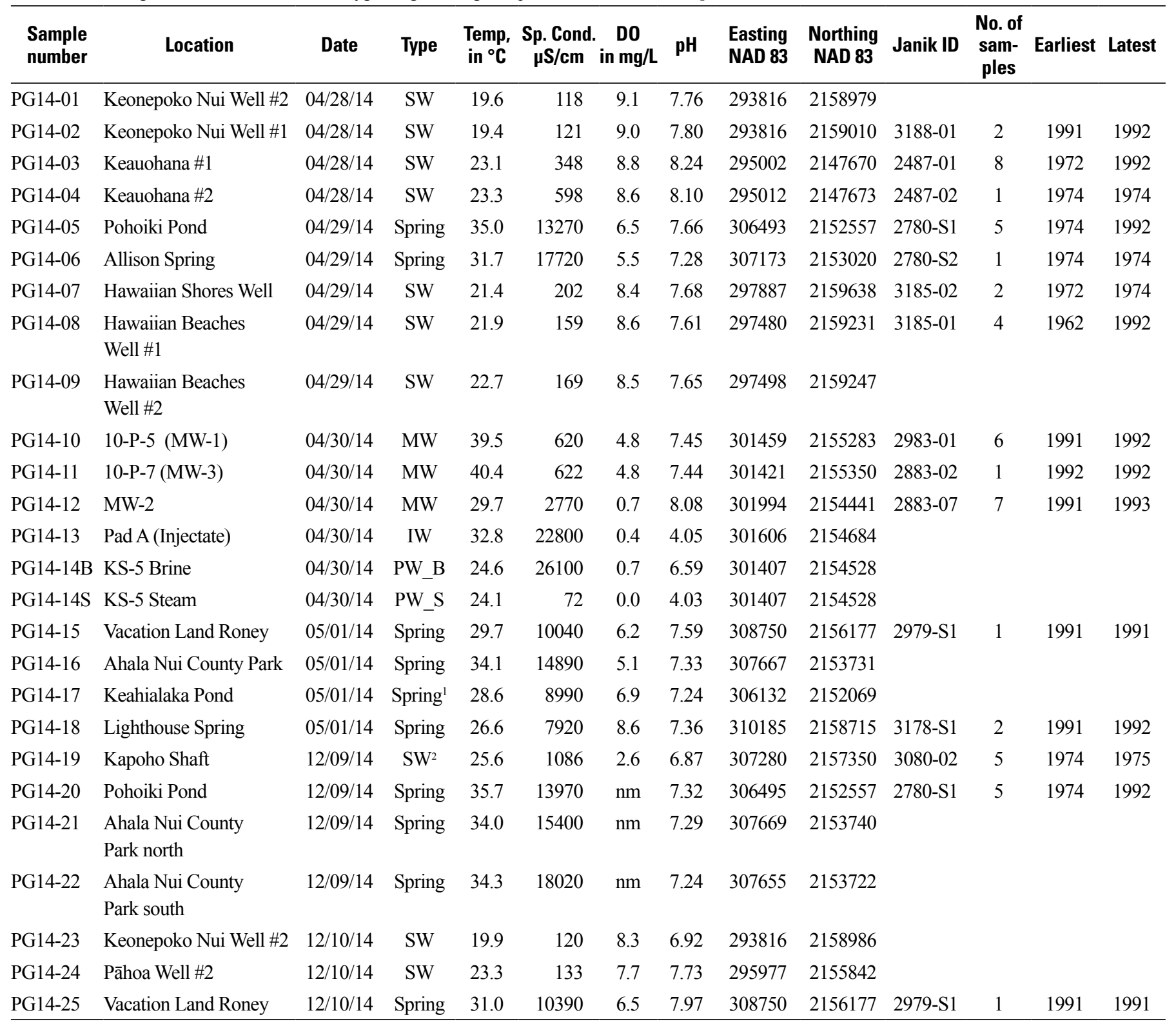

${ }^{1}$ Keahialaka Pond had no visible point of water inflow.

${ }^{2}$ No longer in use. 
Table 2. Concentrations of major and minor dissolved species in milligrams per liter ( $\mathrm{mg} / \mathrm{L})$. Total alkalinity is expressed as $\mathrm{HCO}_{3} ; \mathrm{NO}_{3}$ expressed as $\mathrm{N} ; \mathrm{PO}_{4}$ expressed as $\mathrm{P}$. Balance is calculated as $2(\mathrm{C}-\mathrm{A}) /(\mathrm{C}+\mathrm{A})$ in percent, where $\mathrm{C}$ represents the cations and $A$ represents the anions in milliequivalents per liter (meq/L).

\begin{tabular}{|c|c|c|c|c|c|c|c|c|c|c|}
\hline $\begin{array}{l}\text { Sample } \\
\text { number }\end{array}$ & Location & $\begin{array}{c}B \\
\mathrm{mg} / \mathrm{L}\end{array}$ & $\begin{array}{c}\mathrm{Ba} \\
\mathrm{mg} / \mathrm{L}\end{array}$ & $\underset{\mathrm{mg} / \mathrm{L}}{\mathrm{Br}}$ & $\begin{array}{c}\mathrm{Ca} \\
\mathrm{mg} / \mathrm{L}\end{array}$ & $\underset{\mathrm{mg} / \mathrm{L}}{\mathrm{Cl}}$ & $\begin{array}{c}F \\
m g / L\end{array}$ & $\begin{array}{l}\mathrm{HCO}_{3} \\
\mathrm{mg} / \mathrm{L}\end{array}$ & $\begin{array}{c}\mathrm{K} \\
\mathrm{mg} / \mathrm{L}\end{array}$ & $\begin{array}{c}\mathrm{Li} \\
\mathrm{mg} / \mathrm{L}\end{array}$ \\
\hline PG14-01 & Keonepoko Nui Well \#2 & 0.009 & 0.002 & $<0.01$ & 7.07 & 4.02 & 0.16 & 56 & 2.6 & $<0.001$ \\
\hline PG14-02 & Keonepoko Nui Well \#1 & 0.008 & 0.002 & $<0.01$ & 7.31 & 4.16 & 0.17 & 56 & 2.5 & $<0.001$ \\
\hline PG14-03 & Keauohana \#1 & 0.028 & 0.003 & 0.24 & 8.78 & 75 & 0.21 & 32 & 3.7 & 0.005 \\
\hline PG14-04 & Keauohana $\# 2$ & 0.039 & 0.004 & 0.49 & 12.4 & 150 & 0.24 & 34 & 6.2 & 0.004 \\
\hline PG14-05 & Pohoiki Pond & 1.17 & $<0.025$ & 14.5 & 112 & 4,210 & 1.0 & 52 & 103 & 0.10 \\
\hline PG14-06 & Allison Spring & 1.50 & $<0.025$ & 19.0 & 136 & 5,500 & 1.0 & 55 & 140 & 0.13 \\
\hline PG14-07 & Hawaiian Shores Well & 0.013 & 0.002 & 0.11 & 5.24 & 33.2 & 0.21 & 38 & 3.6 & 0.001 \\
\hline PG14-08 & Hawaiian Beaches Well \#1 & 0.012 & 0.002 & 0.06 & 4.73 & 20.6 & 0.22 & 40 & 3.4 & 0.001 \\
\hline PG14-09 & Hawaiian Beaches Well \#2 & 0.013 & 0.002 & 0.07 & 5.14 & 23.0 & 0.22 & 38 & 3.5 & 0.002 \\
\hline PG14-10 & 10-P-5 (MW-1) & 0.28 & 0.007 & 0.06 & 27.4 & 22.0 & 0.38 & 30 & 12.1 & 0.025 \\
\hline PG14-11 & 10-P-7 (MW-3) & 0.28 & 0.006 & 0.06 & 26.8 & 23.0 & 0.38 & 32 & 12.0 & 0.024 \\
\hline PG14-12 & MW-2 & 0.29 & 0.014 & 2.62 & 41 & 750 & 0.27 & 52 & 22.8 & 0.02 \\
\hline PG14-13 & Pad A (Injectate) & 4.6 & 3.7 & 27.0 & 173 & 7,950 & 1.0 & $\mathrm{~nm}$ & 893 & 2.0 \\
\hline PG14-14B & KS-5 Brine & 6.0 & 3.0 & 30.0 & 147 & 9,120 & 1.0 & 8 & 1,030 & 2.2 \\
\hline PG14-14S & KS-5 Steam & 0.126 & 0.006 & 0.04 & 0.38 & 14.1 & 0.01 & $\mathrm{~nm}$ & 2.0 & 0.003 \\
\hline PG14-15 & Vacation Land Roney & 0.95 & $<0.013$ & 11.0 & 90 & 3,130 & 1.0 & 48 & 83.4 & 0.08 \\
\hline PG14-16 & Ahala Nui County Park & 1.41 & $<0.025$ & 16.5 & 134 & 4,840 & 1.0 & 49 & 135 & 0.15 \\
\hline PG14-17 & Keahialaka Pond & 0.75 & $<0.013$ & 9.5 & 66 & 2,800 & 0.50 & 49 & 62.7 & 0.04 \\
\hline PG14-18 & Lighthouse Spring & 0.68 & $<0.013$ & 8.3 & 78 & 2,410 & 0.75 & 46 & 58.7 & 0.05 \\
\hline PG14-19 & Kapoho Shaft & 0.081 & 0.007 & 0.35 & 75 & 128 & 0.23 & 429 & 8.2 & $<0.002$ \\
\hline PG14-20 & Pohoiki Pond & 1.50 & $<0.041$ & 15.5 & 121 & 4,450 & 0.95 & 64 & 104 & 0.065 \\
\hline PG14-21 & Ahala Nui County Park north & 1.78 & $<0.041$ & 18.0 & 141 & 5,200 & 1.0 & 59 & 136 & 0.13 \\
\hline PG14-22 & Ahala Nui County Park south & 1.72 & $<0.041$ & 20.5 & 152 & 5,850 & 1.0 & 61 & 146 & 0.14 \\
\hline PG14-23 & Keonepoko Nui Well \#2 & 0.012 & 0.002 & $<0.01$ & 6.9 & 4.1 & 0.18 & 59 & 2.5 & $<0.001$ \\
\hline PG14-24 & Pāhoa Well \#2 & 0.023 & 0.002 & 0.010 & 4.2 & 4.8 & 0.29 & 54 & 3.4 & 0.001 \\
\hline PG14-25 & Vacation Land Roney & 1.17 & $<0.021$ & 11.5 & 101 & 3,220 & 1.2 & 58 & 87 & 0.10 \\
\hline
\end{tabular}

Concentrations of the major and minor dissolved species are reported in table 2. Sodium is the dominant cation in all of the waters and chloride the dominant anion in the coastal springs and PGV fluids, reflecting the influence of seawater. Bicarbonate $\left(\mathrm{HCO}_{3}\right)$ is the dominant anion in some of the water supply wells. Several species, such as B, K, Li, Rb, and $\mathrm{SiO}_{2}$, are notably enriched in the PGV injectate and brine, while $\mathrm{Mg}$ is nearly absent. This pattern is a nearly universal characteristic of high-temperature geothermal systems worldwide. $\mathrm{SiO}_{2}$ values in field-diluted PGV samples were within 5 percent of the nondiluted values, indicating that polymerization had not reduced $\mathrm{SiO}_{2}$ concentrations in the undiluted samples. The charge balance between cations and anions is a qualitative measure of analytical error and is less than 5 percent for most of the samples. The balance exceeds 10 percent only for the steam condensate, which is very dilute and subject to larger analytical errors.

Trace elements, including several metals of environmental concern, the stable isotopes of water, and $\mathrm{NH}_{3}$ and $\mathrm{H}_{2} \mathrm{~S}$ concentrations in the PGV samples are reported in table 3 . In general, trace metal levels are low in all of the waters, including the PGV fluids, as pointed out by Thomas (1990). Concentrations of arsenic in the PGV fluids and in some springs exceed the drinking water standard but are actually low in comparison to geothermal fluid compositions worldwide, which often contain more than 1 milligram per liter $(\mathrm{mg} / \mathrm{L})$. The iodometric sulfide titration measures all reduced sulfur species ( $\mathrm{HS}^{-}, \mathrm{S}_{2} \mathrm{O}_{3}^{-}$, etc.), but the nearly 
Table 2. - Continued.

\begin{tabular}{|c|c|c|c|c|c|c|c|c|c|c|c|}
\hline $\begin{array}{l}\text { Sample } \\
\text { number }\end{array}$ & Location & $\underset{\mathrm{mg} / \mathrm{L}}{\mathrm{Mg}}$ & $\begin{array}{c}\mathrm{Na} \\
\mathrm{mg} / \mathrm{L}\end{array}$ & $\begin{array}{l}\mathrm{NO}_{3} \\
\mathrm{mg} / \mathrm{L}\end{array}$ & $\begin{array}{c}\mathrm{PO}_{4} \\
\mathrm{mg} / \mathrm{L}\end{array}$ & $\begin{array}{c}\mathbf{R b} \\
\mathrm{mg} / \mathrm{L}\end{array}$ & $\underset{\mathrm{mg} / \mathrm{L}}{\mathrm{SiO}_{2}}$ & $\underset{\mathrm{mg} / \mathrm{L}}{\mathrm{SO}_{4}}$ & $\begin{array}{c}\mathrm{Sr} \\
\mathrm{mg} / \mathrm{L}\end{array}$ & $\begin{array}{l}\text { TDS } \\
\text { mg/L }\end{array}$ & $\underset{\%}{\text { Balance }}$ \\
\hline PG14-01 & Keonepoko Nui Well \#2 & 4.66 & 9.78 & 0.25 & 0.08 & $<0.01$ & 53 & 4.5 & 0.029 & 135 & 7.3 \\
\hline PG14-02 & Keonepoko Nui Well \#1 & 4.80 & 9.89 & 0.26 & 0.07 & $<0.01$ & 52 & 4.7 & 0.030 & 139 & 8.6 \\
\hline PG14-03 & Keauohana \#1 & 3.99 & 50.4 & 0.27 & 0.08 & $<0.01$ & 50 & 14.1 & 0.046 & 239 & 3.3 \\
\hline PG14-04 & Keauohana \#2 & 7.90 & 86.5 & 0.24 & 0.05 & $<0.02$ & 51 & 23.7 & 0.080 & 367 & -2.1 \\
\hline PG14-05 & Pohoiki Pond & 253 & 2,370 & 1.5 & $<0.5$ & $<0.25$ & 89 & 610 & 1.63 & 7820 & -0.2 \\
\hline PG14-06 & Allison Spring & 321 & 3,080 & 1.5 & $<0.5$ & $<0.25$ & 88 & 780 & 2.05 & 10,100 & -1.0 \\
\hline PG14-07 & Hawaiian Shores Well & 5.66 & 23.4 & 0.26 & 0.06 & $<0.01$ & 56 & 7.8 & 0.031 & 174 & 5.3 \\
\hline PG14-08 & Hawaiian Beaches Well \#1 & 4.12 & 18.1 & 0.25 & 0.07 & $<0.01$ & 58 & 6.4 & 0.025 & 156 & 4.2 \\
\hline PG14-09 & Hawaiian Beaches Well \#2 & 4.42 & 19.6 & 0.25 & 0.06 & $<0.01$ & 59 & 6.7 & 0.026 & 160 & 8.9 \\
\hline PG14-10 & 10-P-5 (MW-1) & 14.6 & 67.4 & 0.26 & $<0.02$ & 0.027 & 106 & 218 & 0.095 & 511 & -2.0 \\
\hline PG14-11 & 10-P-7 (MW-3) & 14.5 & 68.0 & 0.20 & $<0.02$ & 0.026 & 106 & 220 & 0.096 & 513 & -2.9 \\
\hline PG14-12 & MW-2 & 29.3 & 460 & $<0.01$ & $<0.01$ & $<0.05$ & 62 & 136 & 0.34 & 1560 & 0.9 \\
\hline PG14-13 & Pad A (Injectate) & 0.2 & 4,420 & 7.0 & 1.0 & 2.36 & 597 & 17.0 & 5.17 & 14,100 & -0.3 \\
\hline PG14-14B & KS-5 Brine & 0.1 & 5,180 & 2.0 & $<1$ & 2.74 & 714 & 25.0 & 4.40 & 16,300 & 0.5 \\
\hline PG14-14S & KS-5 Steam & 0.004 & 9.4 & $<0.01$ & $<0.01$ & $<0.01$ & 2 & 0.5 & 0.010 & 29 & 16.5 \\
\hline PG14-15 & Vacation Land Roney & 188 & 1,770 & 1.0 & $<0.5$ & $<0.13$ & 73 & 515 & 1.27 & 5,910 & -1.1 \\
\hline PG14-16 & Ahala Nui County Park & 277 & 2,740 & 1.5 & $<0.5$ & $<0.25$ & 97 & 675 & 1.90 & 8,970 & 0.6 \\
\hline PG14-17 & Keahialaka Pond & 172 & 1,580 & 1.5 & $<0.25$ & $<0.13$ & 61 & 408 & 1.01 & 5,210 & -0.5 \\
\hline PG14-18 & Lighthouse Spring & 152 & 1,380 & 0.50 & $<0.25$ & $<0.13$ & 60 & 393 & 1.05 & 4,590 & 1.3 \\
\hline PG14-19 & Kapoho Shaft & 40 & 94.8 & 2.4 & 0.09 & $<0.02$ & 60 & 16.4 & 0.29 & 854 & 3.0 \\
\hline PG14-20 & Pohoiki Pond & 263 & 2,430 & 1.5 & $<0.5$ & $<0.41$ & 91 & 640 & 1.71 & 8,180 & -2.9 \\
\hline PG14-21 & Ahala Nui County Park north & 293 & 2,850 & 1.5 & $<0.5$ & $<0.41$ & 97 & 715 & 2.01 & 9,510 & -2.6 \\
\hline PG14-22 & Ahala Nui County Park south & 340 & 3,150 & 0.50 & $<0.5$ & $<0.41$ & 92 & 815 & 2.25 & 10,600 & -3.7 \\
\hline PG14-23 & Keonepoko Nui Well \#2 & 4.55 & 9.4 & 0.22 & 0.06 & $<0.01$ & 52 & 4.5 & 0.027 & 143 & 0.2 \\
\hline PG14-24 & Pāhoa Well \#2 & 3.10 & 16.5 & $<0.01$ & 0.05 & $<0.01$ & 57 & 12.2 & 0.020 & 155 & -1.7 \\
\hline PG14-25 & Vacation Land Roney & 204 & 1,840 & 1.0 & $<0.5$ & $<0.21$ & 81 & 525 & 1.40 & 6,130 & 1.3 \\
\hline
\end{tabular}

complete partitioning of reduced sulfur into the steam and gas phase - $510 \mathrm{mg} / \mathrm{L}$ versus $9 \mathrm{mg} / \mathrm{L}$ in the brine - shows that the primary reduced sulfur species is $\mathrm{H}_{2} \mathrm{~S}$.

\section{Gas Chemistry}

The gas bubbles collected from the PGV steam and injectate lines are somewhat similar in bulk composition (table 4). This is expected, given that between these two sampling ports PGV pumps the gas from the steam line into the injectate line. Major constituents in both samples include $\mathrm{H}_{2}, \mathrm{CO}_{2}$ and $\mathrm{H}_{2} \mathrm{~S}$, all of which are commonly found in geothermal systems. The $\mathrm{N}_{2}$ and Ar are likely derived from the atmosphere, in part from air dissolved in rainwater or seawater that ultimately recharges the geothermal reservoir. The presence of oxygen at low levels indicates that only a small amount of air contamination occurred during sample collection.

The noticeable differences in composition between the steam and injectate samples (table 4) mainly reflect variation in the solubility of the individual gas species and the volume ratio between gas bubbles and water in the sampling line. More soluble gases like $\mathrm{H}_{2} \mathrm{~S}$ and $\mathrm{CO}_{2}$ are less able to partition into the small bubbles that form in the injectate sampling line; they remain in solution and are therefore at lower concentrations in the injectate gas sample relative to the steam sample. Less soluble gases like $\mathrm{H}_{2}, \mathrm{Ar}$, and $\mathrm{N}_{2}$ get concentrated in those small bubbles; for example, $\mathrm{N}_{2}$ is nearly a factor of 2 higher in the injectate gas sample. 
Table 3. Concentrations of trace metals, $\mathrm{NH}_{3^{\prime}}$ and $\mathrm{H}_{2} \mathrm{~S}$, in milligrams per liter (mg/L), and stable isotopes of water, in per mil. $\mathrm{NH}_{3}$ values expressed as $\mathrm{N} ; \mathrm{H}_{2} \mathrm{~S}$ values are total reduced $\mathrm{S}$ expressed as $\mathrm{H}_{2} \mathrm{~S}$.

[nm, not measured]

\begin{tabular}{|c|c|c|c|c|c|c|c|c|c|}
\hline SAMPLE \# & Location & $\begin{array}{c}\mathrm{Al} \\
\mathrm{mg} / \mathrm{L}\end{array}$ & $\begin{array}{c}\text { As } \\
\mathrm{mg} / \mathrm{L}\end{array}$ & $\begin{array}{c}\mathrm{Cd} \\
\mathrm{mg} / \mathrm{L}\end{array}$ & $\begin{array}{c}\mathrm{Co} \\
\mathrm{mg} / \mathrm{L}\end{array}$ & $\begin{array}{c}\mathrm{Cr} \\
\mathrm{mg} / \mathrm{L}\end{array}$ & $\begin{array}{c}\mathrm{Cu} \\
\mathrm{mg} / \mathrm{L}\end{array}$ & $\begin{array}{c}\mathrm{Fe} \\
\mathrm{mg} / \mathrm{L}\end{array}$ & $\begin{array}{c}\mathrm{Mn} \\
\mathrm{mg} / \mathrm{L}\end{array}$ \\
\hline PG14-01 & Keonepoko Nui Well \#2 & $<0.002$ & 0.001 & $<0.001$ & $<0.001$ & 0.003 & 0.001 & $<0.003$ & $<0.001$ \\
\hline PG14-02 & Keonepoko Nui Well \#1 & 0.002 & $<0.001$ & $<0.001$ & $<0.001$ & 0.003 & $<0.001$ & $<0.003$ & $<0.001$ \\
\hline PG14-03 & Keauohana \#1 & 0.006 & 0.001 & $<0.001$ & $<0.001$ & $<0.001$ & $<0.001$ & 0.004 & $<0.001$ \\
\hline PG14-04 & Keauohana \#2 & $<0.004$ & $<0.002$ & $<0.002$ & $<0.002$ & $<0.002$ & $<0.002$ & $<0.006$ & $<0.002$ \\
\hline PG14-05 & Pohoiki Pond & $<0.05$ & $<0.025$ & $<0.025$ & $<0.025$ & $<0.025$ & $<0.025$ & $<0.075$ & $<0.025$ \\
\hline PG14-06 & Allison Spring & $<0.05$ & 0.03 & $<0.025$ & $<0.025$ & $<0.025$ & $<0.025$ & $<0.075$ & $<0.025$ \\
\hline PG14-07 & Hawaiian Shores Well & $<0.002$ & 0.001 & $<0.001$ & $<0.001$ & 0.001 & 0.002 & $<0.003$ & $<0.001$ \\
\hline PG14-08 & Hawaiian Beaches Well \#1 & $<0.002$ & $<0.001$ & $<0.001$ & $<0.001$ & 0.002 & $<0.001$ & $<0.003$ & $<0.001$ \\
\hline PG14-09 & Hawaiian Beaches Well \#2 & 0.002 & 0.001 & $<0.001$ & $<0.001$ & 0.001 & 0.003 & $<0.003$ & $<0.001$ \\
\hline PG14-10 & 10-P-5 (MW-1) & 0.003 & $<0.001$ & $<0.001$ & $<0.001$ & $<0.001$ & $<0.001$ & 0.013 & 0.002 \\
\hline PG14-11 & 10-P-7 (MW-3) & 0.003 & 0.001 & $<0.001$ & $<0.001$ & $<0.001$ & $<0.001$ & 0.015 & 0.005 \\
\hline PG14-12 & MW-2 & $<0.01$ & $<0.005$ & $<0.005$ & $<0.005$ & $<0.005$ & $<0.005$ & 0.018 & 0.04 \\
\hline PG14-13 & Pad A (Injectate) & 0.18 & 0.053 & $<0.05$ & $<0.05$ & $<0.05$ & $<0.05$ & 0.17 & 0.3 \\
\hline PG14-14B & KS-5 Brine & 0.24 & 0.069 & $<0.05$ & $<0.05$ & $<0.05$ & 0.065 & $<0.15$ & 0.6 \\
\hline PG14-14S & KS-5 Steam & 0.007 & $<0.001$ & $<0.001$ & $<0.001$ & $<0.001$ & $<0.001$ & 0.02 & 0.022 \\
\hline PG14-15 & Vacation Land Roney & $<0.026$ & 0.02 & $<0.013$ & $<0.013$ & $<0.013$ & $<0.013$ & $<0.039$ & $<0.013$ \\
\hline PG14-16 & Ahala Nui County Park & $<0.05$ & $<0.025$ & $<0.025$ & $<0.025$ & $<0.025$ & $<0.025$ & $<0.075$ & $<0.025$ \\
\hline PG14-17 & Keahialaka Pond & $<0.026$ & 0.01 & $<0.013$ & $<0.013$ & $<0.013$ & $<0.013$ & $<0.039$ & $<0.013$ \\
\hline PG14-18 & Lighthouse Spring & $<0.026$ & 0.01 & $<0.013$ & $<0.013$ & $<0.013$ & $<0.013$ & $<0.039$ & $<0.013$ \\
\hline PG14-19 & Kapoho Shaft & $<0.01$ & $<0.02$ & $<0.002$ & $<0.002$ & $<0.002$ & 0.002 & $<0.006$ & $<0.002$ \\
\hline PG14-20 & Pohoiki Pond & $<0.2$ & $<0.04$ & $<0.04$ & $<0.04$ & $<0.04$ & $<0.04$ & $<0.12$ & $<0.04$ \\
\hline PG14-21 & Ahala Nui County Park north & $<0.2$ & $<0.04$ & $<0.04$ & $<0.04$ & $<0.04$ & $<0.04$ & $<0.12$ & $<0.04$ \\
\hline PG14-22 & Ahala Nui County Park south & $<0.2$ & $<0.04$ & $<0.04$ & $<0.04$ & $<0.04$ & $<0.04$ & $<0.12$ & $<0.04$ \\
\hline PG14-23 & Keonepoko Nui Well \#2 & $<0.005$ & $<0.01$ & $<0.001$ & $<0.001$ & 0.003 & 0.002 & $<0.003$ & $<0.001$ \\
\hline PG14-24 & Pāhoa Well \#2 & $<0.005$ & $<0.01$ & $<0.001$ & $<0.001$ & 0.001 & 0.006 & $<0.003$ & $<0.001$ \\
\hline PG14-25 & Vacation Land Roney & $<0.1$ & $<0.21$ & $<0.2$ & $<0.2$ & $<0.2$ & $<0.2$ & $<0.06$ & $<0.2$ \\
\hline
\end{tabular}

The gases contain trace amounts of numerous hydrocarbons, from methane to compounds as large as pentane. Pentane and other hydrocarbons were clearly detectable on the TCD detector used to quantify major constituents, even though this detector is not highly sensitive to hydrocarbons. The more precise values obtained from the FID are used in further discussion, but either set of results would produce the same conclusions.

The alkane hydrocarbon concentrations (as parts-permillion by volume) are shown in figure 2 . Alkanes up to butane, which has two isomers, are enriched about two-fold in the injectate relative to the steam sample. This enrichment likely reflects their low aqueous solubilities, similar to those of $\mathrm{Ar}$ and $\mathrm{N}_{2}$, which show comparable enrichments (table 4). Thus, no in-plant source is required to explain the fact that these alkane concentrations are higher in the injectate than in the produced steam. Pentane, in contrast, shows a sixfold enrichment in the injectate relative to the steam (fig. 2), consistent with an in-plant source.

The alkane hydrocarbons consist mainly of methane, and both samples show successively decreasing amounts of ethane, propane, and butane (fig. 2). This is the pattern expected in virtually any natural gas, whether from a sedimentary basin or a geothermal system, where alkanes form from the thermal breakdown of organic matter (for example, kerogen) in the reservoir (Darling, 1998; Tassi and others, 2007). Successively higher molecular weight alkanes like pentane and hexane normally continue the trend of decreasing abundance. The PGV samples instead show a conspicuous increase in pentane, again consistent with an artificial source. The gas in the 
Table 3. - Continued.

\begin{tabular}{|c|c|c|c|c|c|c|c|c|c|}
\hline SAMPLE \# & Location & $\begin{array}{c}\mathrm{Mo} \\
\mathrm{mg} / \mathrm{L}\end{array}$ & $\begin{array}{c}\mathrm{Ni} \\
\mathrm{mg} / \mathrm{L}\end{array}$ & $\begin{array}{c}\mathrm{Se} \\
\mathrm{mg} / \mathrm{L}\end{array}$ & $\begin{array}{c}\mathrm{Zn} \\
\mathrm{mg} / \mathrm{L}\end{array}$ & $\begin{array}{c}\mathrm{NH}_{3} \\
\mathrm{mg} / \mathrm{L}\end{array}$ & $\begin{array}{c}\mathrm{H}_{2} \mathrm{~S} \\
\mathrm{mg} / \mathrm{L}\end{array}$ & $\begin{array}{c}\delta D \\
\text { per mil }\end{array}$ & $\begin{array}{c}\delta^{18} 0 \\
\text { per mil }\end{array}$ \\
\hline PG14-01 & Keonepoko Nui Well \#2 & $<0.001$ & $<0.001$ & $<0.005$ & 0.006 & $\mathrm{~nm}$ & $\mathrm{~nm}$ & -22.1 & -4.43 \\
\hline PG14-02 & Keonepoko Nui Well \#1 & $<0.001$ & $<0.001$ & $<0.005$ & 0.006 & $\mathrm{~nm}$ & $\mathrm{~nm}$ & -23.5 & -4.51 \\
\hline PG14-03 & Keauohana \#1 & $<0.001$ & $<0.001$ & $<0.005$ & 0.005 & $\mathrm{~nm}$ & $\mathrm{~nm}$ & -15.0 & -3.61 \\
\hline PG14-04 & Keauohana \#2 & $<0.002$ & $<0.002$ & $<0.01$ & 0.005 & $\mathrm{~nm}$ & $\mathrm{~nm}$ & -14.6 & -3.58 \\
\hline PG14-05 & Pohoiki Pond & $<0.025$ & $<0.025$ & $<0.125$ & $<0.05$ & $\mathrm{~nm}$ & $\mathrm{~nm}$ & -9.9 & -2.54 \\
\hline PG14-06 & Allison Spring & $<0.025$ & $<0.025$ & $<0.125$ & $<0.05$ & $\mathrm{~nm}$ & $\mathrm{~nm}$ & -9.1 & -2.36 \\
\hline PG14-07 & Hawaiian Shores Well & $<0.001$ & $<0.001$ & $<0.005$ & 0.007 & $\mathrm{~nm}$ & $\mathrm{~nm}$ & -13.7 & -3.50 \\
\hline PG14-08 & Hawaiian Beaches Well \#1 & $<0.001$ & $<0.001$ & $<0.005$ & 0.004 & $\mathrm{~nm}$ & $\mathrm{~nm}$ & -13.9 & -3.50 \\
\hline PG14-09 & Hawaiian Beaches Well \#2 & $<0.001$ & $<0.001$ & $<0.005$ & 0.007 & $\mathrm{~nm}$ & $\mathrm{~nm}$ & -15.0 & -3.46 \\
\hline PG14-10 & 10-P-5 (MW-1) & 0.002 & $<0.001$ & $<0.005$ & 0.004 & $\mathrm{~nm}$ & $\mathrm{~nm}$ & -12.1 & -3.18 \\
\hline PG14-11 & 10-P-7 (MW-3) & 0.002 & $<0.001$ & $<0.005$ & 0.084 & $\mathrm{~nm}$ & $\mathrm{~nm}$ & -12.7 & -3.30 \\
\hline PG14-12 & MW-2 & $<0.005$ & $<0.005$ & $<0.025$ & $<0.01$ & $\mathrm{~nm}$ & $\mathrm{~nm}$ & -12.1 & -3.20 \\
\hline PG14-13 & Pad A (Injectate) & $<0.05$ & $<0.05$ & $<0.25$ & $<0.1$ & $<0.04$ & 122 & -8.1 & -1.55 \\
\hline PG14-14B & KS-5 Brine & $<0.05$ & $<0.05$ & $<0.25$ & $<0.1$ & $<0.04$ & 9 & -5.6 & -0.80 \\
\hline PG14-14S & KS-5 Steam & $<0.001$ & $<0.001$ & 0.01 & $<0.002$ & $<0.04$ & 510 & -6.1 & -3.00 \\
\hline PG14-15 & Vacation Land Roney & $<0.013$ & $<0.013$ & $<0.065$ & $<0.026$ & $\mathrm{~nm}$ & $\mathrm{~nm}$ & -8.3 & -2.51 \\
\hline PG14-16 & Ahala Nui County Park & $<0.025$ & $<0.025$ & $<0.125$ & $<0.05$ & $\mathrm{~nm}$ & $\mathrm{~nm}$ & -8.3 & -2.32 \\
\hline PG14-17 & Keahialaka Pond & $<0.013$ & $<0.013$ & $<0.065$ & $<0.026$ & $\mathrm{~nm}$ & $\mathrm{~nm}$ & -10.9 & -2.80 \\
\hline PG14-18 & Lighthouse Spring & $<0.013$ & $<0.013$ & $<0.065$ & $<0.026$ & $\mathrm{~nm}$ & $\mathrm{~nm}$ & -10.5 & -2.91 \\
\hline PG14-19 & Kapoho Shaft & $<0.002$ & $<0.002$ & $<0.01$ & $<0.004$ & $\mathrm{~nm}$ & $\mathrm{~nm}$ & -15.4 & -3.44 \\
\hline PG14-20 & Pohoiki Pond & $<0.04$ & $<0.04$ & $<0.2$ & $<0.08$ & $\mathrm{~nm}$ & $\mathrm{~nm}$ & -9.0 & -2.31 \\
\hline PG14-21 & Ahala Nui County Park north & $<0.04$ & $<0.04$ & $<0.2$ & $<0.08$ & $\mathrm{~nm}$ & $\mathrm{~nm}$ & -7.4 & -2.14 \\
\hline PG14-22 & Ahala Nui County Park south & $<0.04$ & $<0.04$ & $<0.2$ & $<0.08$ & $\mathrm{~nm}$ & $\mathrm{~nm}$ & -7.9 & -2.04 \\
\hline PG14-23 & Keonepoko Nui Well \#2 & $<0.001$ & $<0.001$ & $<0.005$ & 0.015 & $\mathrm{~nm}$ & $\mathrm{~nm}$ & -20.7 & -4.42 \\
\hline PG14-24 & Pāhoa Well \#2 & 0.001 & $<0.001$ & $<0.005$ & 0.062 & $\mathrm{~nm}$ & $\mathrm{~nm}$ & -14.1 & -3.75 \\
\hline PG14-25 & Vacation Land Roney & $<0.2$ & $<0.2$ & $<0.1$ & $<0.04$ & $\mathrm{~nm}$ & $\mathrm{~nm}$ & -8.7 & -2.44 \\
\hline
\end{tabular}

injectate stream also contains a significant amount of pentene (table 4), a compound not detected in the produced steam. The PGV gases contain no hexane, which would likely be detectable if all of the other hydrocarbons derived from natural degradation of organic matter in the reservoir.

Thermal degradation of large hydrocarbons into smaller ones is a complex process (Darling, 1998). Although a full explanation of the hydrocarbon abundance patterns in the PGV gases cannot be provided, several assertions can be supported. The working fluid used by PGV is nearly pure pentane (99.2 percent according to the material safety data sheet supplied by PGV). At some point in the plant, perhaps in the heat exchanger, pentane enters the flow system. Some degradation to pentene must occur upstream from the injectate sampling port (table 4). Such a rapid reaction is possible in this case because $\mathrm{H}_{2} \mathrm{~S}$ is known to catalyze hydrocarbon degradation under certain conditions (Xia and others, 2014). The pentene apparently breaks down into smaller hydrocarbons after injection into the reservoir, because it is not present in the produced steam (table 4). The injected pentane may also continue to break down into smaller hydrocarbons, but enough survives within the reservoir that it exceeds the abundance of butane (both isomers) in the produced steam. It is not possible with existing data to precisely distinguish hydrocarbons generated by thermal breakdown of organic matter in the reservoir from those produced by pentane degradation. Although some of the pentane may come from natural sources in the reservoir, it is clear from the data that the geothermal plant must be an important source. 
Table 4. Composition (in volume percent) of gas bubbles in samples collected from the Puna Geothermal Venture steam and injectate lines.

$[T C D$, results from the gas chromatograph equipped with a thermal conductivity detector; FID, results from the gas chromatograph equipped with a flame ionization detector; nm, not measured]

\begin{tabular}{|c|c|c|c|c|c|}
\hline \multirow{2}{*}{\multicolumn{2}{|c|}{$\begin{array}{l}\text { Sample } \\
\text { Method }\end{array}$}} & \multicolumn{2}{|c|}{$\begin{array}{l}\text { PG14-14S } \\
\text { steam line }\end{array}$} & \multicolumn{2}{|c|}{$\begin{array}{c}\text { PG14-13 } \\
\text { injectate line }\end{array}$} \\
\hline & & TCD & FID & TCD & FID \\
\hline \multicolumn{6}{|c|}{ Bulk gas analysis } \\
\hline Helium & $\mathrm{He}$ & $<0.01$ & $\mathrm{~nm}$ & $<0.01$ & $\mathrm{~nm}$ \\
\hline Hydrogen & $\mathrm{H}_{2}$ & 33.0 & $\mathrm{~nm}$ & 42.2 & $\mathrm{~nm}$ \\
\hline Argon & $\mathrm{Ar}$ & 0.276 & $\mathrm{~nm}$ & 0.412 & $\mathrm{~nm}$ \\
\hline Oxygen & $\mathrm{O}_{2}$ & 0.346 & $\mathrm{~nm}$ & 0.120 & $\mathrm{~nm}$ \\
\hline Nitrogen & $\mathrm{N}_{2}$ & 15.4 & $\mathrm{~nm}$ & 27.2 & $\mathrm{~nm}$ \\
\hline Carbon Dioxide & $\mathrm{CO}_{2}$ & 27.8 & $\mathrm{~nm}$ & 21.4 & $\mathrm{~nm}$ \\
\hline Hydrogen Sulfide & $\mathrm{H}_{2} \mathrm{~S}$ & 25.2 & $\mathrm{~nm}$ & 10.5 & $\mathrm{~nm}$ \\
\hline Carbon Monoxide & $\mathrm{CO}$ & $<0.001$ & $\mathrm{~nm}$ & $<0.001$ & $\mathrm{~nm}$ \\
\hline \multicolumn{6}{|c|}{ Hydrocarbons } \\
\hline Methane & $\mathrm{CH}_{4}$ & 0.226 & 0.193 & 0.421 & 0.372 \\
\hline Ethylene & $\mathrm{C}_{2} \mathrm{H}_{4}$ & 0.0003 & 0.0003 & 0.0003 & 0.0003 \\
\hline Ethane & $\mathrm{C}_{2} \mathrm{H}_{6}$ & 0.017 & 0.0148 & 0.029 & 0.0267 \\
\hline Propylene & $\mathrm{C}_{3} \mathrm{H}_{6}$ & 0.003 & 0.0027 & 0.003 & 0.0025 \\
\hline Propane & $\mathrm{C}_{3} \mathrm{H}_{8}$ & 0.006 & 0.0068 & 0.012 & 0.0131 \\
\hline Butane & $\mathrm{n}-\mathrm{C}_{4} \mathrm{H}_{10}$ & 0.001 & 0.0016 & 0.003 & 0.0036 \\
\hline Isobutane & $\mathrm{i}-\mathrm{C}_{4} \mathrm{H}_{10}$ & 0.002 & 0.0025 & 0.004 & 0.0056 \\
\hline Pentene & $\mathrm{C}_{5} \mathrm{H}_{10}$ & $<0.001$ & $<0.0002$ & 0.014 & 0.0086 \\
\hline Pentane & $\mathrm{C}_{5} \mathrm{H}_{12}$ & 0.005 & 0.0060 & 0.031 & 0.0398 \\
\hline Hexane & $\mathrm{C}_{6} \mathrm{H}_{14}$ & $<0.01$ & $<0.003$ & $<0.01$ & $<0.004$ \\
\hline
\end{tabular}

Figure 2. Concentration of alkane hydrocarbons (in parts-per-million by volume) in gas samples from the steam (blue) and injectate (red) pipelines at Puna Geothermal Venture. Concentration of methane divided by 10 .

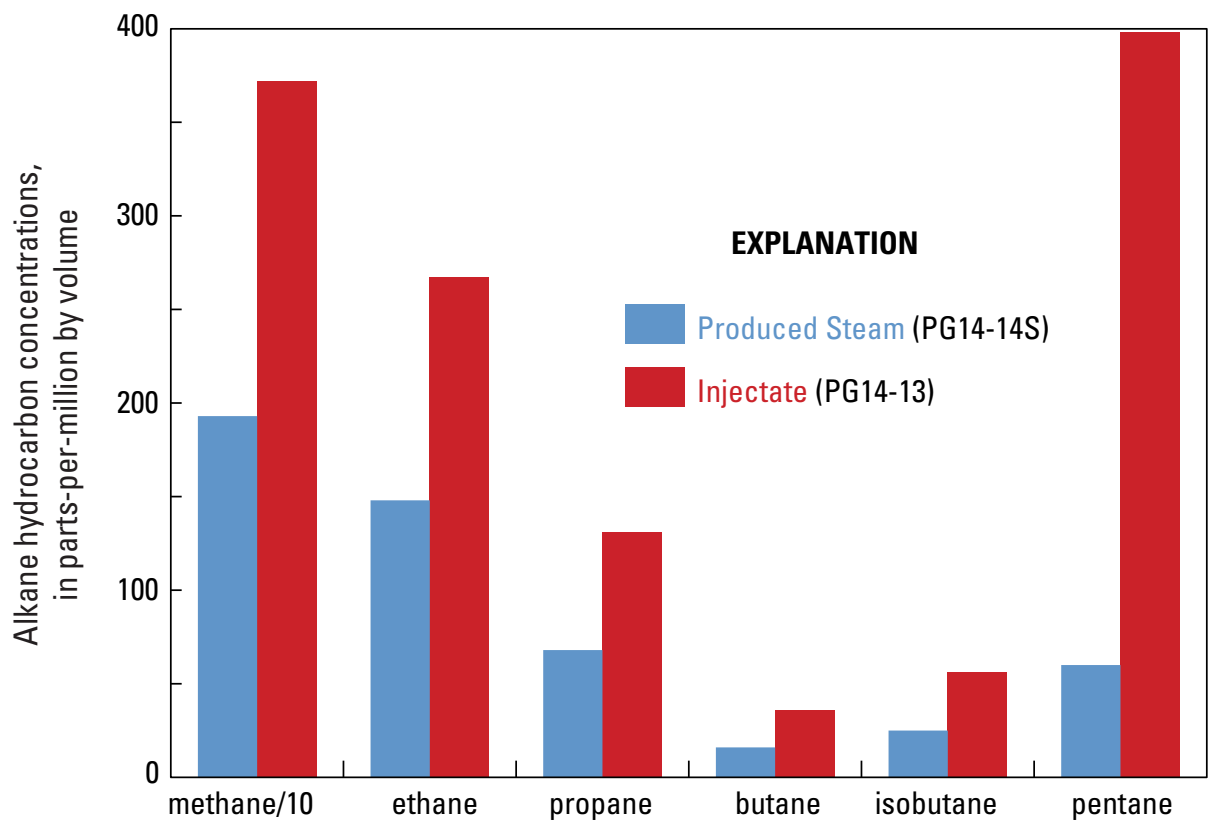


Table 5. Concentrations of dissolved hydrocarbons in micromoles per kilogram $(\mu \mathrm{mol} / \mathrm{kg})$ for all samples containing a hydrocarbon larger than methane. DIC and serum bottle samplers discussed in text.

[nm, not measured]

\begin{tabular}{|c|c|c|c|c|c|c|c|c|c|c|c|c|c|}
\hline \multirow{2}{*}{$\begin{array}{l}\text { Sample } \\
\text { Method }\end{array}$} & \multicolumn{2}{|c|}{$\begin{array}{l}\text { PG14-14S } \\
\text { Steam }\end{array}$} & \multirow{2}{*}{\begin{tabular}{|c|}
$\begin{array}{c}\text { PG14-13 } \\
\text { Injectate }^{1}\end{array}$ \\
(serum) \\
\end{tabular}} & \multicolumn{2}{|c|}{$\begin{array}{l}\text { PG14-14B } \\
\text { Brine } \\
\end{array}$} & \multicolumn{2}{|c|}{$\begin{array}{l}\text { PG14-12 } \\
\text { MW-2 }\end{array}$} & \multicolumn{2}{|c|}{\begin{tabular}{|c|} 
PG14-01 \\
Keonepoko Nui \#2 \\
\end{tabular}} & \multicolumn{2}{|c|}{$\begin{array}{c}\text { PG14-19 } \\
\text { Kapoho Shaft }\end{array}$} & \multicolumn{2}{|c|}{$\begin{array}{l}\text { PG14-24 } \\
\text { Pāhoa \#2 } \\
\end{array}$} \\
\hline & (DIC) & (serum) & & (DIC) & (serum) & (DIC) & (serum) & (DIC) & (serum) & (DIC) & (serum) & (DIC) & (serum) \\
\hline $\mathrm{C}_{2} \mathrm{H}_{4}$ & $<0.01$ & $\mathrm{~nm}$ & $\mathrm{~nm}$ & 0.007 & $\mathrm{~nm}$ & $<0.01$ & $\mathrm{~nm}$ & $<0.01$ & $\mathrm{~nm}$ & $<0.01$ & $\mathrm{~nm}$ & $<0.01$ & $\mathrm{~nm}$ \\
\hline $\mathrm{C}_{2} \mathrm{H}_{6}$ & 0.18 & 0.11 & 0.35 & 0.007 & 0.002 & 0.01 & 0.01 & 0.008 & $<0.001$ & 0.005 & $<0.001$ & 0.008 & $<0.001$ \\
\hline $\mathrm{C}_{3} \mathrm{H}_{8}$ & 0.05 & 0.01 & 0.06 & $<0.01$ & 0.001 & 0.01 & 0.01 & $<0.01$ & $<0.001$ & 0.007 & $<0.001$ & $<0.01$ & $<0.001$ \\
\hline $\mathrm{n}-\mathrm{C}_{4} \mathrm{H}_{10}$ & 0.01 & 0.005 & 0.02 & $<0.01$ & 0.0003 & 0.01 & 0.005 & 0.007 & $<0.001$ & $<0.01$ & $<0.001$ & $<0.01$ & $<0.001$ \\
\hline $\mathrm{i}-\mathrm{C}_{4} \mathrm{H}_{10}$ & 0.01 & 0.004 & 0.03 & 0.004 & $<0.001$ & 0.003 & 0.001 & $<0.01$ & $<0.001$ & $<0.01$ & $<0.001$ & $<0.01$ & $<0.001$ \\
\hline $\mathrm{C}_{5} \mathrm{H}_{10}$ & $<0.01$ & $\mathrm{~nm}$ & $\mathrm{~nm}$ & 0.02 & $\mathrm{~nm}$ & $<0.01$ & $\mathrm{~nm}$ & $<0.01$ & $\mathrm{~nm}$ & $<0.01$ & $\mathrm{~nm}$ & $<0.01$ & $\mathrm{~nm}$ \\
\hline
\end{tabular}

${ }^{1}$ DIC bottle broken in shipment

\section{Pentane in Water Samples}

For the purpose of this study, a criterion is needed to identify a PGV-related hydrocarbon component in groundwater that might also contain hydrocarbons from natural sources. An excess of pentane relative to total butane is an obvious criterion to apply, given the gas sample results discussed above, but for thoroughness the water samples collected for pentane analysis were analyzed for the full hydrocarbon abundance patterns as was done for the gas samples. Traces of methane were found at every site, but this is a common gas that can be formed through microbial activity in many groundwaters. The results for every site where a hydrocarbon larger than methane was detected are shown in table 5 .

Two caveats about these data must be acknowledged. Collection and analysis of water samples containing these highly insoluble gases involves several steps where gas concentrations can be altered. For example, the tiny bubbles that frequently form during collection can result in significant depletion or enrichment of gas within the actual water sample. Thus even duplicate samples analyzed by the same method can show large differences. A particular concern for this sample set is the low concentration of most hydrocarbons. The original goal of the study was to attain a detection limit for pentane of $1 \mathrm{microgram} / \mathrm{kilogram}$ of water, which equates to 0.014 micromoles $/$ kilogram $(\mu \mathrm{mol} / \mathrm{kg})$. The method using the DIC bottles attained this detection limit, while the serum bottle method achieved a much lower detection limit of $0.001 \mu \mathrm{mol} / \mathrm{kg}$. For completeness, a value is reported in table 5 for every case where an identifiable peak was seen in the chromatogram, even in cases where the concentration was below the stated detection limit. The identity of the compound is fairly certain; however, for the many values near the respective detection limits, the concentration carries a large uncertainty.

Despite the uncertainties, pentane exceeds total butane in the steam (using both sampling methods) and especially in the injectate (table 5). Because visible gas loss occurred during collection of these samples (bubbles in the collection tubing), these values are minimum concentrations. The brine sample is gas poor by comparison, having lost nearly all of its gas to the steam phase. A few hydrocarbons are detectable at low levels, mainly alkenes which are more soluble than alkanes. Several hydrocarbons were detected by both methods in MW-2 near the plant, including a trace of pentane in the serum bottle.

Hydrocarbons larger than methane were only detected at three other sites (table 5) and, in each case, only detected in the DIC bottles at levels close to the detection limits of that method. The April DIC sample from Keonepoko Nui well \#2 showed several alkane peaks, including pentane, but neither of the two serum bottles from that well showed any hydrocarbons other than methane. This well was resampled in December, and no hydrocarbons (other than methane) were detected by either method. Thus the alkane detects for the one DIC sample, all of which are less than $0.01 \mathrm{mmol} / \mathrm{kg}$, may reflect low-level contamination of that sample bottle during initial evacuation or analysis. Pentane was not detected at any other site, but DIC bottles from Kapoho Shaft and the Pāhoa supply well showed some trace hydrocarbons larger than methane. Serum bottles from these wells showed only methane, so perhaps the results from these DIC bottles also reflect low-level contamination in the bottles. However, such hydrocarbons can also be produced from organic matter (for example, pipe grease) within well 
plumbing systems and be flushed out intermittently as the well pumps are cycled on and off. Samples collected only minutes apart could reflect this variation, and thus the data should not be automatically disregarded.

Alkane abundances are shown in figure 3 for the sites where pentane was detected. The abundances in MW-2 (PG1412) do not show the pentane enrichment pattern seen in the injectate, and instead show a steady decrease in abundance with increasing molecular size. If these alkanes originated as pentane from the PGV injectate, thermal degradation of that pentane has proceeded to the point where the abundance pattern is indistinguishable from that expected to result from degradation of natural organic matter. The alkane abundances in the Keonepoko Nui \#2 (PG14-01) DIC sample from April 2014 look nothing like the pattern in the injectate, MW-2, or any typical groundwater, and are considered unlikely to represent the groundwater feeding this well. Thus there was no clear evidence for PGV-derived pentane in any of the groundwater features we sampled.

\section{Isopropanol}

Isopropanol (isopropyl alcohol) is a component of the additive ChemTreat GG442 used by PGV to control corrosion in pipelines at the plant. The concentration range of isopropanol in the additive is listed as $1-5$ percent by weight in the material safety data sheet obtained from PGV, and a more precise figure could not be obtained from the manufacturer. PGV records for the month of April 2014 show that, on an average day, 52 gallons of additive are mixed into 5 million gallons of injectate, a mixing ratio of about $10 \mathrm{mg}$ of additive per liter of injectate, ignoring density differences between the two fluids. Isopropanol should thus constitute between 100 and 500 micrograms per liter $(\mu \mathrm{g} / \mathrm{L})$ of the injectate. The measured isopropanol concentration in the sample of injectate (PG14-13) was $496 \mathrm{mg} / \mathrm{L}$, consistent with 5 percent isopropanol in the additive.

Unlike pentane, isopropanol is quite soluble in water, so that partitioning into gas bubbles during sample collection at ambient temperature is not a significant concern. At high temperatures, volatility does become important, and most of the injected isopropanol that survives transport through the reservoir to the production well partitions into the steam line. The isopropanol concentration in PG14-14S was $60.5 \mathrm{mg} / \mathrm{L}$; that in PG14-14B was $3.8 \mathrm{mg} / \mathrm{L}$. Interestingly, the ratio of isopropanol concentration in injectate to that in steam is 8.2:1, not too different from the pentane ratio for injectate to steam, which is $6.4: 1$ based on the average pentane concentration in the two steam samples in table 5. Either the two compounds degrade at comparable rates in the reservoir, or they degrade very little and the concentration ratios reflect the reservoir dilution factor. Isopropanol was below detection $(<0.8 \mathrm{mg} / \mathrm{L})$ in all samples, except for the three collected from the plant, and thus provided no evidence for PGVderived fluid in the groundwaters.

Isopropanol analysis also yielded results for 37 other VOCs. The complete list of these compounds, representative detection limits, and instances of detection are shown in table 6 . In nearly every instance, concentrations are near the detection limits, and the reported concentrations should be viewed with caution unless confirmed by future sampling. The single exception is the reported concentration of isopropyl acetate in the injectate sample. This compound may be an impurity in the ChemTreat GG442 additive or a reaction product derived from isopropanol in the piping system. Apart from isopropanol and possibly isopropyl acetate, the compounds in table 6 are not known to be contaminants specifically related to geothermal production.
Figure 3. Concentration of alkane hydrocarbons (in $\mu \mathrm{mol} / \mathrm{kg}$ ) in both wells where pentane was detected, MW-2 (PG14-12) and Keonepoko Nui \#2 (PG14-01— ${ }^{*}$ DIC sample only). Red bars show concentrations in the injectate sample (PG14-13) for comparison. Concentration of methane divided by 10 .

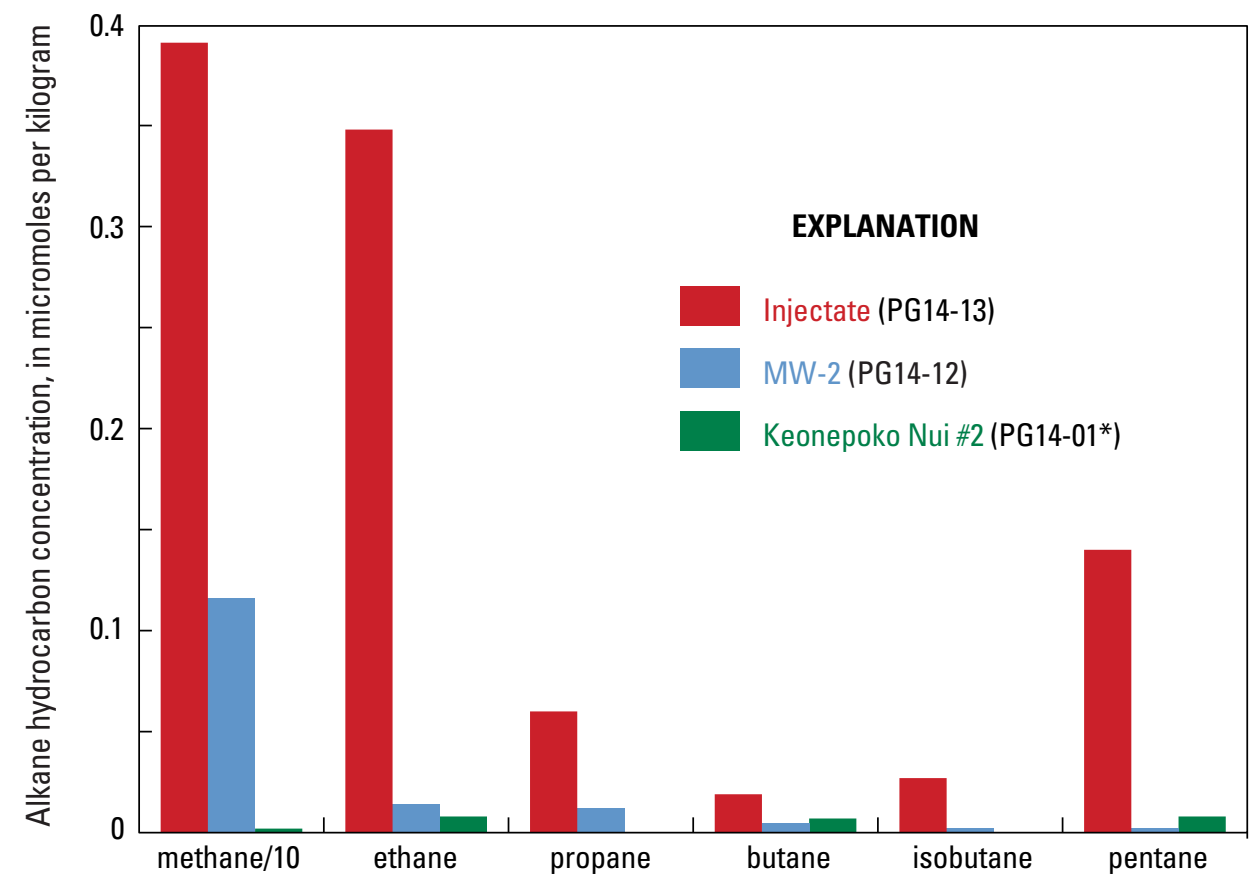




\section{Injectate Composition Over Time}

Direct leakage of deep geothermal water or gas into shallow groundwater would likely first be detected at sites nearest to the plant, in this case the three monitoring wells. Contaminant transport in shallow groundwater to remote locations like the coastal warm springs $5-10 \mathrm{~km}$ away would be controlled by groundwater velocity from the LERZ down to the coast. Scholl and others (1996) used tritium data to estimate residence times of 18-25 years for the groundwater feeding these springs, though some of this time could include periods of slow flow through dike-impounded zones within the LERZ. Hydraulic conductivity between the rift and the coastal warm springs is thought to be in the range of 1-6 km/d (Imada, 1984; Takasaki; 1993; Gingerich, 1995). Given the hydraulic gradient and effective porosity south of the rift zone (Gingerich, 1995), groundwater flow expressed as particle velocity relevant to contaminant transport is likely to range from about 3 to $30 \mathrm{~m} / \mathrm{d}$ (Sorey and Colvard, 1994). Thus it might require several years for any contaminant derived from the PGV plant to appear at the springs. Evaluation of contamination in these features also requires some knowledge of geothermal fluid composition in previous years.

The injectate is sampled on a regular basis to satisfy conditions of the operating permit. Bimonthly samples are analyzed for a suite of inorganic species similar to that presented in tables 2 and 3. Samples of gas from the noncondensable gas line, taken just before it flows into the injectate stream, are also analyzed. Additional samples of the injectate are collected twice a year for specialized analyses that include a large suite of organic compounds, but not isopropanol. The records are extensive, and we obtained a partial set from the $\mathrm{HDOH}$ that provided inorganic chemistry and gas composition for 2008-14 and selected prior years.

\section{Pentane and Isopropanol}

Analyses of pentane in injectate apparently began on November 3, 2000, when it constituted 0.632 percent of the noncondensable gas. Values since that time have generally been an order of magnitude lower, and in the samples collected just before and after our sampling were near 0.02 percent (fig. 4). Our gas sample, PG14-13, has a somewhat higher value, near 0.04 percent, but this sample was collected from the injectate pipeline instead of the noncondensable gas line, where samples are normally obtained. The two-fold difference is probably due to solubility effects as discussed above.

Although the rate at which pentane enters the injectate stream continues to show variability (fig. 4), it seems reasonable to assume that the measured concentration of dissolved pentane in our injectate sample, $0.14 \mathrm{mmol} / \mathrm{kg}$ (table 5), is representative of average conditions over the past six years. Given the detection limit of $0.001 \mathrm{mmol} / \mathrm{kg}$ by the serum bottle method, pentane could be detectable in springs and wells that contain as little as 1 percent injectate. Pentane would thus be a good indicator of leaks in the event of casing failure in an injection well. However, pentane concentrations in the deep reservoir are no doubt substantially less than those in the injectate due to degradation and (or) dilution. Furthermore, pentane could be lost to exsolution during groundwater flow over many kilometers from the PGV area, so the absence of pentane in coastal springs, for example, does not in itself preclude contamination by geothermal fluid.

PGV use of isopropanol began in September 2013, so groundwater transport of this compound would not be expected to extend far (many kilometers) from the plant at the time of our sampling. Our motivation in measuring isopropanol in distal sites was mainly to obtain a complete picture of natural background levels, enhancing possible future use as a tracer.
Figure 4. Concentration of pentane (in volume percent) in the noncondensable gas line at Puna Geothermal Venture, as reported in Hawai'i State Department of Health records for 2001 , 2004, and 2007-14. Value for initial report of November 3,2000 , is off scale and shown by the arrow. Black diamond shows the pentane concentration we measured in gas bubbles from the injectate line.

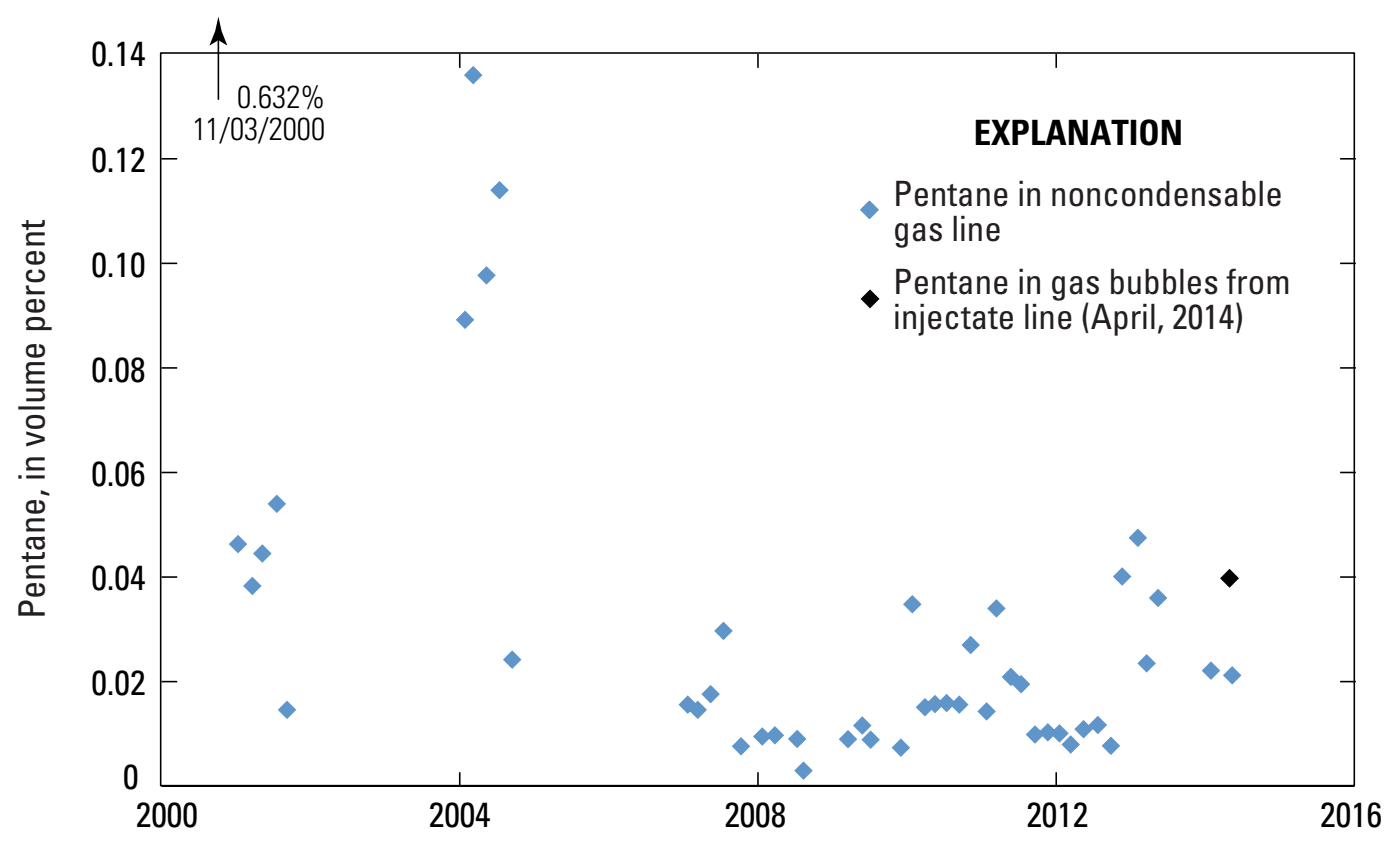


Table 6. Volatile organic compounds (VOCs) measured in water samples. VOCs were below detection in all other samples.

[All samples measured in micrograms per liter; detections in bold]

\begin{tabular}{|c|c|c|c|c|c|c|}
\hline & $\begin{array}{c}\text { PG14-01 } \\
\text { Keonepoko } \\
\text { Nui \#2 }\end{array}$ & $\begin{array}{c}\text { PG14-02 } \\
\text { Keonepoko } \\
\text { Nui \#1 }\end{array}$ & $\begin{array}{l}\text { PG14-12 } \\
\text { Monitoring } \\
\text { Well } 2\end{array}$ & $\begin{array}{c}\text { PG14-13 } \\
\text { PGV } \\
\text { injectate }\end{array}$ & $\begin{array}{l}\text { PG14-14S } \\
\text { PGV } \\
\text { steam }\end{array}$ & $\begin{array}{c}\text { PG14-14B } \\
\text { PGV } \\
\text { brine }\end{array}$ \\
\hline acrolein & $<0.24$ & $<0.24$ & $<0.325$ & $<0.599$ & $<0.471$ & $<0.48$ \\
\hline hexachlorocyclopentadiene & $<1.6$ & $<1.6$ & $<1.6$ & $<1.6$ & $<1.6$ & $<3.2$ \\
\hline isophorone & $<5$ & $<5$ & $<5$ & $<5$ & $<5$ & $<10$ \\
\hline nitrobenzene & $<0.6$ & $<0.6$ & $<0.6$ & $<0.6$ & $<0.6$ & $<1.2$ \\
\hline 1,2-dichloropropane & $<0.004$ & $<0.004$ & $<0.004$ & $<0.004$ & $<0.004$ & $<0.008$ \\
\hline isopropyl acetate & $<0.01$ & $<0.01$ & $<0.01$ & 0.17 & $<0.01$ & $<0.02$ \\
\hline propyl acetate & 0.08 & 0.04 & $<0.032$ & $<0.032$ & $<0.032$ & $<0.064$ \\
\hline 1-methoxy-4-(2-propenyl)benzene & $<0.6$ & $<0.6$ & $<0.6$ & $<0.6$ & $<0.6$ & $<1.2$ \\
\hline 2-ethoxyethyl acetate & $<4.2$ & $<4.2$ & $<4.2$ & $<4.2$ & $<4.2$ & $<8.4$ \\
\hline 2-propen-1-ol & $<5$ & $<5$ & $<5$ & $<5$ & $<5$ & $<10$ \\
\hline alpha-terpineol & $<6$ & $<6$ & $<6$ & $<6$ & $<6$ & $<12$ \\
\hline butanal & $<0.38$ & $<0.38$ & $<0.38$ & $<0.38$ & 0.2 & 0.2 \\
\hline crotonaldehyde & $<0.48$ & $<0.48$ & $<0.48$ & $<0.48$ & $<0.48$ & $<0.96$ \\
\hline acetonitrile & $<0.8$ & $<0.8$ & $<0.8$ & $<0.8$ & $<0.8$ & $<1.6$ \\
\hline isopropanol & $<0.8$ & $<0.8$ & $<0.8$ & 496 & 60.5 & 3.8 \\
\hline methyl acetate & $<0.14$ & $<0.14$ & $<0.14$ & $<0.14$ & $<0.14$ & $<0.28$ \\
\hline 1-butanol & $<0.8$ & $<0.8$ & $<0.8$ & $<0.8$ & $<0.8$ & $<1.6$ \\
\hline tert-butyl alcohol & $<0.24$ & $<0.24$ & 0.24 & $<0.248$ & 0.5 & $<0.48$ \\
\hline n-pentanal & $<0.054$ & $<0.054$ & $<0.054$ & $<0.188$ & $<0.428$ & 0.04 \\
\hline 2-nitropropane & $<0.12$ & $<0.12$ & $<0.12$ & $<0.12$ & $<0.12$ & $<0.24$ \\
\hline cyclohexanone & $<1.2$ & $<1.2$ & $<1.2$ & $<1.2$ & $<1.2$ & $<2.4$ \\
\hline 4-methyl-2-pentanol & $<0.2$ & $<0.2$ & $<0.2$ & $<0.2$ & $<0.2$ & $<0.4$ \\
\hline 5-methyl-2-hexanone & $<0.022$ & $<0.022$ & $<0.022$ & $<0.0240$ & $<0.0762$ & $<0.044$ \\
\hline 2-methylpropyl acetate & $<0.028$ & $<0.028$ & $<0.028$ & $<0.028$ & $<0.028$ & $<0.056$ \\
\hline 1-octanol & $<1.8$ & $<1.8$ & $<1.8$ & $<1.8$ & $<1.8$ & $<3.6$ \\
\hline 2-ethyl-1-hexanol & $<2$ & $<2$ & $<2$ & $<2$ & $<2$ & $<4$ \\
\hline 2,6-dimethyl-4-heptanone & $<0.032$ & $<0.032$ & $<0.032$ & $<0.032$ & $<0.032$ & $<0.064$ \\
\hline 1,2,3-trichloropropane & $<0.006$ & $<0.006$ & $<0.006$ & $<0.006$ & $<0.006$ & $<0.012$ \\
\hline chloropicrin & $<0.018$ & $<0.018$ & $<0.018$ & $<0.018$ & $<0.018$ & $<0.036$ \\
\hline 1,2-dibromoethane & $<0.004$ & $<0.004$ & $<0.004$ & $<0.004$ & $<0.004$ & $<0.008$ \\
\hline tert-butyl methyl ether & $<0.012$ & $<0.012$ & $<0.012$ & $<0.012$ & $<0.012$ & $<0.024$ \\
\hline n-nitrosodiethylamine & $<3.6$ & $<3.6$ & $<3.6$ & $<3.6$ & $<3.6$ & $<7.2$ \\
\hline 1,1-dichloro-2-propanone & $<0.24$ & $<0.24$ & $<0.24$ & $<0.24$ & $<0.24$ & $<0.48$ \\
\hline dimethoxymethane & $<0.044$ & $<0.044$ & $<0.044$ & $<0.044$ & $<0.044$ & $<0.088$ \\
\hline 1,4-dioxane & $<0.7$ & $<0.7$ & $<0.7$ & $<0.7$ & 1 & $<1.4$ \\
\hline 1,3-dioxolane & $<0.38$ & $<0.38$ & $<0.38$ & $<0.38$ & $<0.38$ & $<0.76$ \\
\hline ethyl acetate & $<0.06$ & $<0.06$ & $<0.06$ & $<0.06$ & $<0.06$ & $<0.12$ \\
\hline dibromochloropropane & $<0.02$ & $<0.02$ & $<0.02$ & $<0.02$ & $<0.02$ & $<0.04$ \\
\hline
\end{tabular}


The aqueous solubility of isopropanol at low temperature exceeds that of pentane by a factor of $10^{5}$, suggesting that it would be much more likely to remain in solution during groundwater transport.

\section{Water and Gas Composition of Injectate}

Seawater is an important source of fluid for the geothermal reservoir, and thus the chemical composition of PGV fluid has many of the characteristics of seawater. Rainfall is abundant and infiltration rapid in the Puna area (Thomas, 1987; Takasaki, 1993; Ingebritsen and Scholl, 1993; Gingerich, 1995; Scholl and others, 1995), and some of this infiltration reaches the reservoir, causing variable dilution of the seawater component. Injectate monitoring records from $\mathrm{HDOH}$ show that $\mathrm{NaCl}$ content has nearly doubled since 1995, but that the rate of increase has slowed greatly over the last 15 years (fig. 5). During the last six years the $\mathrm{Na}$ and $\mathrm{Cl}$ concentrations have been reasonably constant and are near the concentration in our injectate sample, $\mathrm{PG} 14-13$. The $\mathrm{Na} / \mathrm{Cl}$ ratio has followed the seawater dilution line. The injectate has always been low in sulfate, which is almost completely removed into solid phases or converted to reduced forms at the high temperatures in and adjacent to the reservoir. Interestingly, the fluid composition in the HGP-A well showed a similar evolution during its years of production (Thomas, 1987; Janik and others, 1994), leveling off at about the same composition as present-day PGV fluid.

The concentrations of several major species over the past six years, including a sample collected two weeks after our injectate sample, are shown in figure 6. While some species (Ca, total S) show significant short-term variability (fig. 6B), long-term trends are not readily apparent.

Gas composition (in the noncondensable gas line) has also been reasonably stable over the past six years and even farther back into the late 1990s (fig. 7), although the minor gases $\mathrm{CH}_{4}$ and Ar have shown a long-term increases (fig. $7 B$ ). The dominant gas species are typically $\mathrm{H}_{2}$ and $\mathrm{CO}_{2}$, with lesser amounts of $\mathrm{N}_{2}$ and $\mathrm{H}_{2} \mathrm{~S}$. Our gas sample from the injectate line is somewhat richer in $\mathrm{H}_{2}$ and $\mathrm{N}_{2}$ and depleted in $\mathrm{CO}_{2}$ and $\mathrm{H}_{2} \mathrm{~S}$, due to the

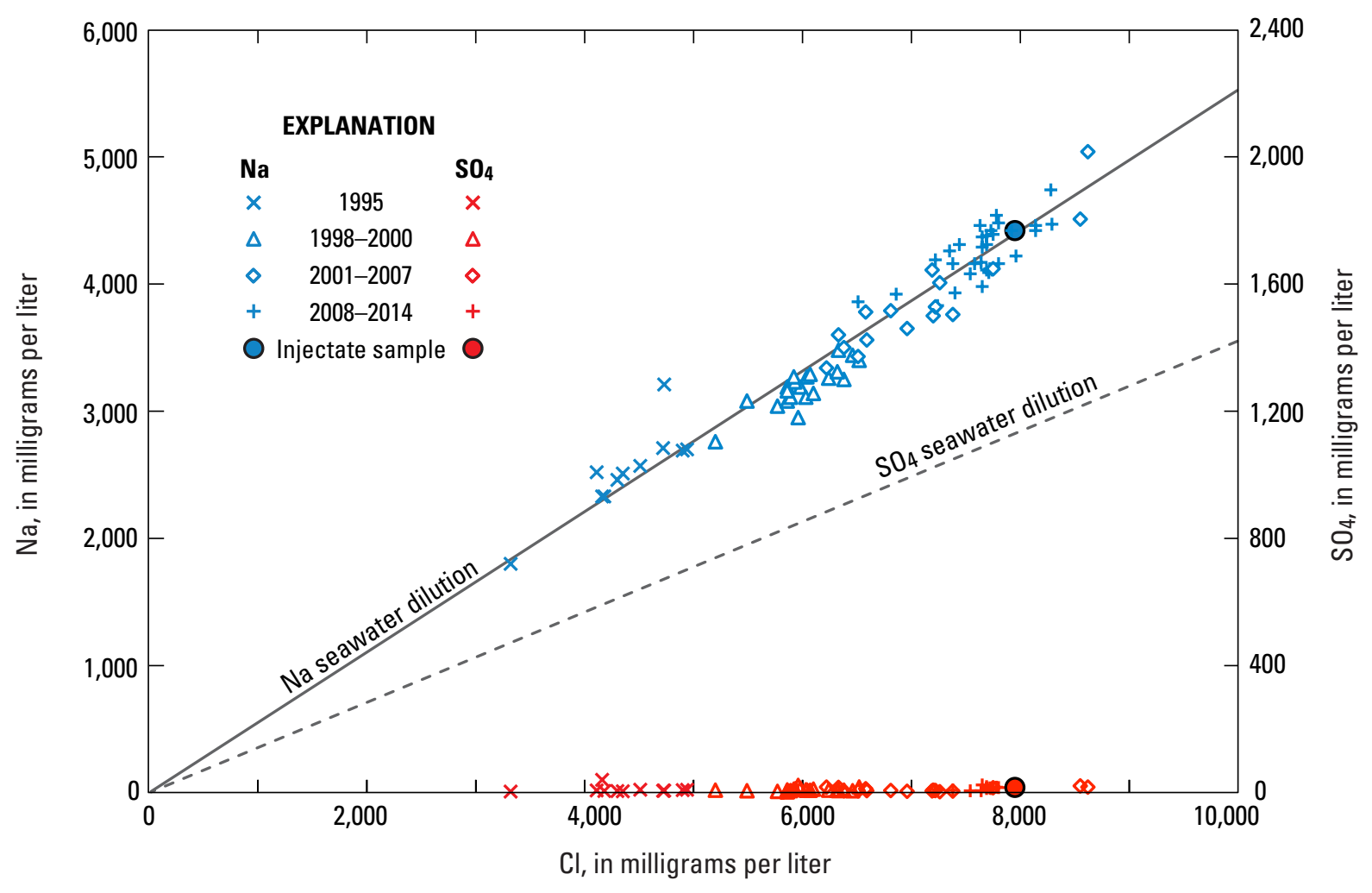

Figure 5. Concentration (in $\mathrm{mg} / \mathrm{L}$ ) of $\mathrm{Na}$ (blue) and $\mathrm{SO}_{4}$ (red) versus $\mathrm{Cl}$ in injectate over time, based on Hawaii i State Department of Health records. The record is broken into four time increments: 1995 (crosses); 1998-2000 (triangles); 2001-07 (diamonds); and 2008-14 (pluses). Filled circles show composition of our injectate sample on April 30, 2014. Solid and dashed lines are seawater dilution lines for $\mathrm{Na}$ and $\mathrm{SO}_{4}$, respectively. 
solubility effects discussed above, but is nevertheless similar in composition to the HDOH data from the last six years.

The stable chemical composition of the injectate during the past six years provides a straightforward test for a component of reservoir fluid in the groundwater, specifically by searching for any trend in groundwater chemistry toward the injectate composition. We conduct the test using a series of plots that have the $\mathrm{Cl}$ on the $\mathrm{x}$-axis and show dilution lines that would result from mixing a saline fluid (like seawater or injectate) with pure water. The properties and benefits of such plots were discussed in detail by Janik and others (1994). Using pure-water as an end member means that the dilution lines are independent of actual groundwater chemistry, helping to focus on the processes responsible for deviations of any particular groundwater from the dilution lines; for example, mineral solution reactions.

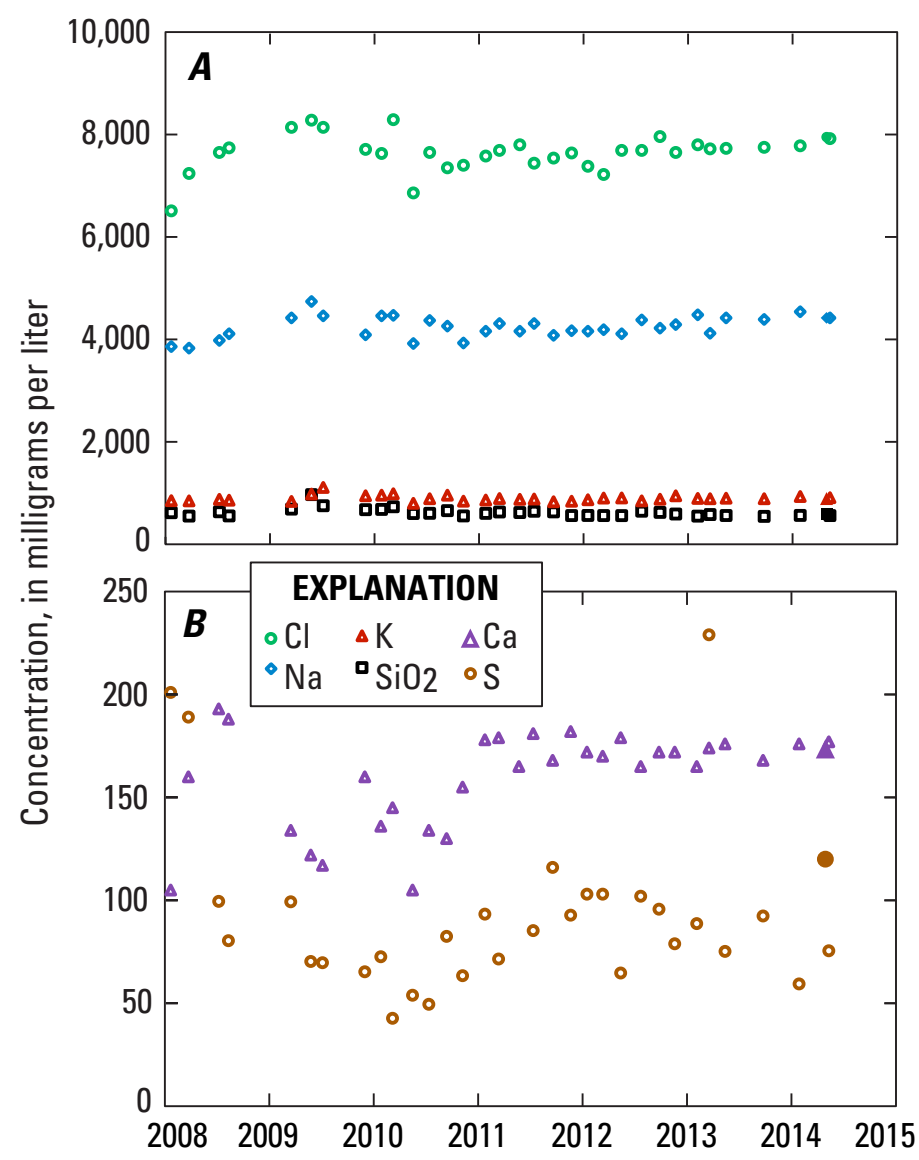

Figure 6. Concentration (in $\mathrm{mg} / \mathrm{L}$ ) of several major chemical species in the injectate over time, based on Hawai'i State Department of Health records (open symbols). Filled symbols show concentrations of the same species in our injectate sample of April 30, 2014. A) Na (diamonds), $\mathrm{K}$ (red triangles), $\mathrm{Cl}$ (green circles), $\mathrm{SiO}_{2}$ (squares); $B$ ) $\mathrm{Ca}$ (purple triangles), $\mathrm{S}$ (brown circles) which represent total sulfate and reduced sulfur as $\mathrm{S}$.

\section{Groundwater Chemistry}

Groundwater chemistry is plotted at different salinity scales, with figure 8 emphasizing results from springs and figure 9 focused on the less-saline groundwater wells. Seawater, with $19,000 \mathrm{mg} / \mathrm{L} \mathrm{Cl}$, exceeds the range of the $\mathrm{x}$-axis but is represented by a dilution line on all plots. For consistency with Janik and others (1994), we use the composition of seawater from Hem (1985). When the injectate value exceeds the range of the axes, an injectate dilution line is shown based on sample PG14-13.

The six species used in these plots (figs. 8 and 9) were chosen for their contrasting behaviors in geothermal systems. In general, $\mathrm{Na}$ behaves as a conservative species that, like $\mathrm{Cl}$, primarily reflects source waters; $\mathrm{K}$ and $\mathrm{B}$ have additional mineral sources and tend to become enriched in water as temperature increases; $\mathrm{Mg}$ partitions out of solution into

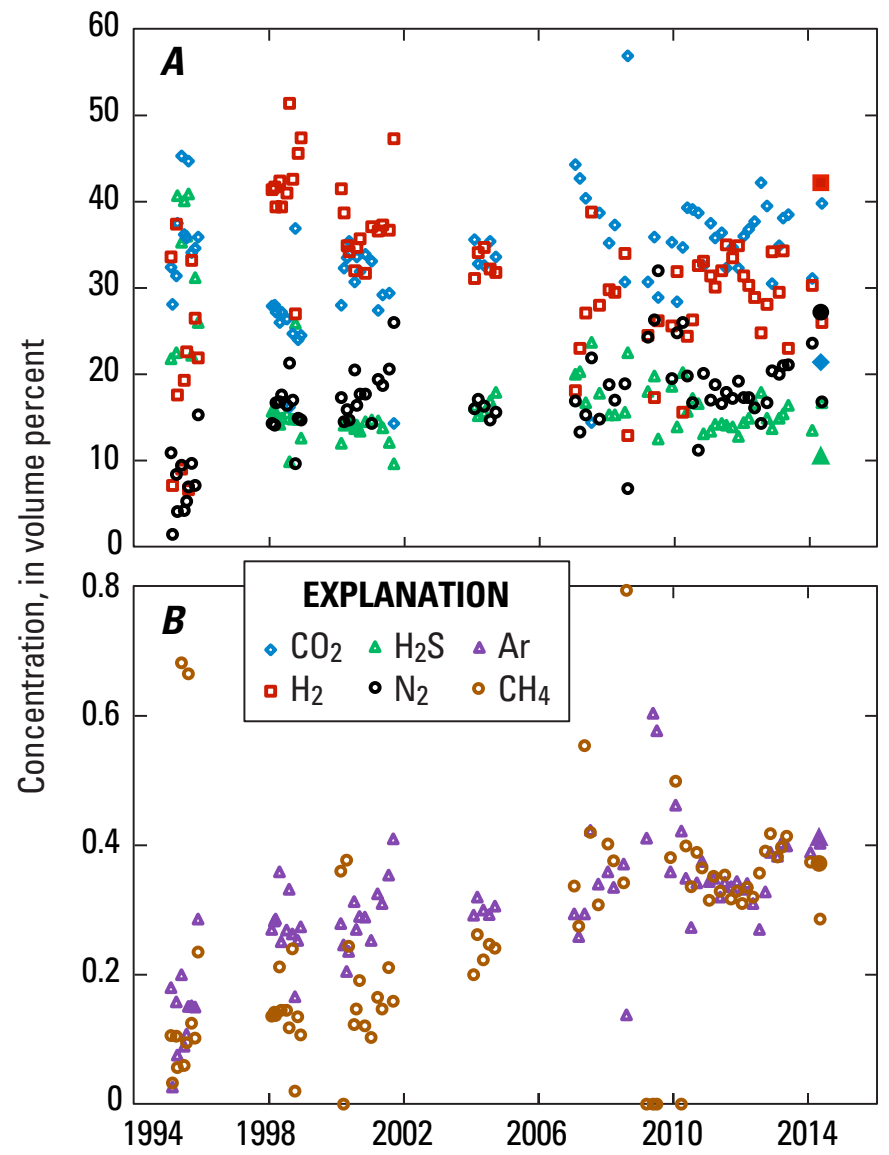

Figure 7. Concentration (in volume percent) of gas species (other than pentane) in the noncondensable gas line over time, based on Hawaii i State Department of Health records for 1995, 1998, 2000, 2001, 2004, and 2007-14 (open symbols). Filled symbols show concentrations of the same species in our injectate sample of April 30, 2014. A) $\mathrm{CO}_{2}$ (diamonds), $\mathrm{H}_{2}$ (squares), $\mathrm{H}_{2} \mathrm{~S}$ (green triangles), $\mathrm{N}_{2}$ (black circles); $B$ ) $\mathrm{Ar}$ (purple triangles), $\mathrm{CH}_{4}$ (brown circles). 

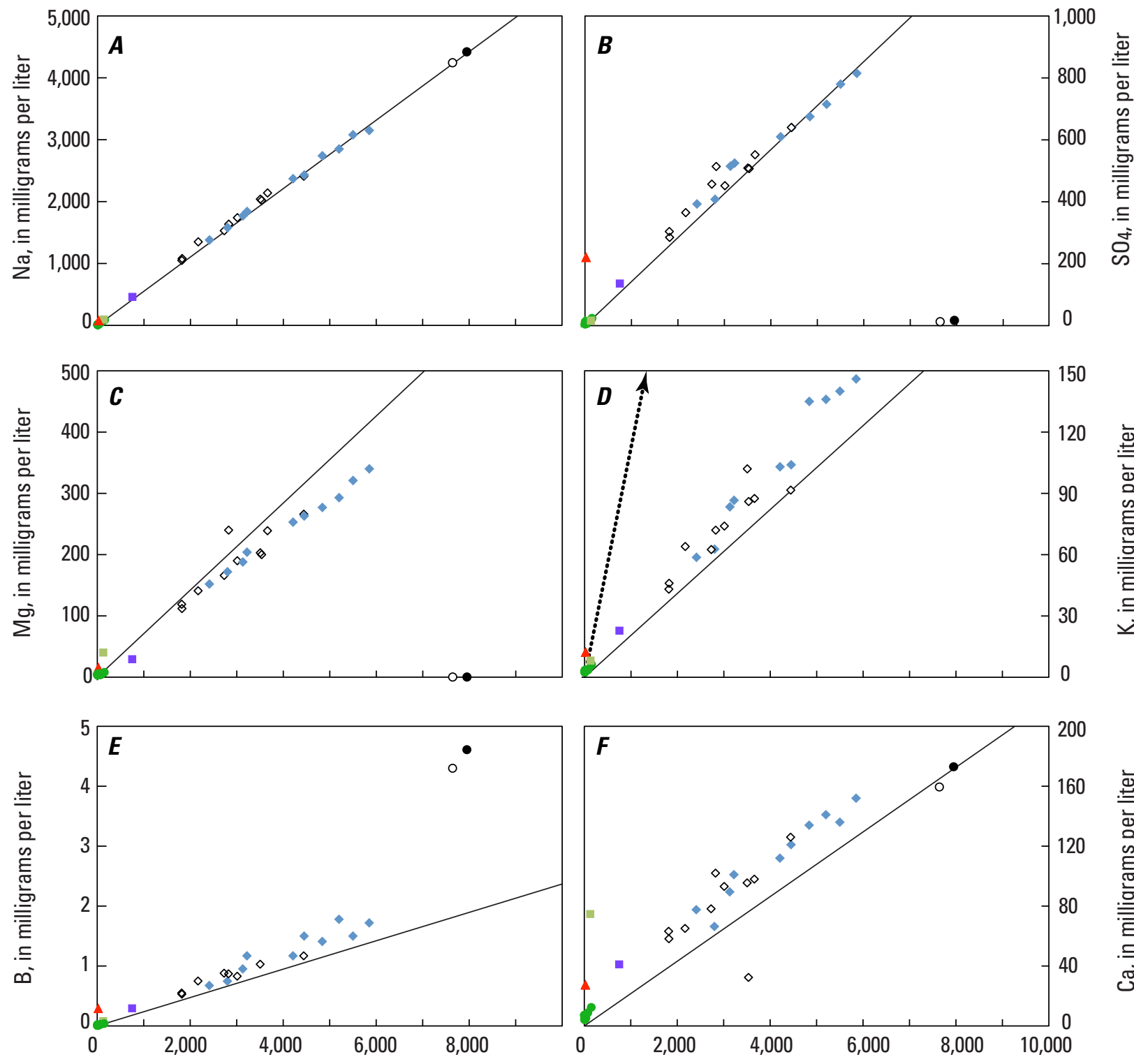

$\mathrm{Cl}$, in milligrams per liter

Figure 8. Concentration of six chemical species relative to $\mathrm{Cl}$. Filled symbols are data from this study: water-supply wells, green circles; Kapoho Shaft, green square; MW-1 and MW-3, which co-locate at this scale, red triangles; MW-2, purple square; coastal springs, blue diamonds; injectate, black circle. Open black diamonds are spring data reported in Janik and others (1994). Open black circle is average injectate composition for 200814 from Hawaili State Department of Health records. Solid lines extend to the composition of seawater at $19,000 \mathrm{mg} / \mathrm{L} \mathrm{Cl}$; dashed arrow in $D$ extends

- Water-supply wells

- Kapoho Shaft

- MW-1, MW-3

- MW-2

- Coastal springs

- Injectate

$\diamond$ Springs, pre-1993

○ Injectate avg. 2008-14

- Seawater

.... Injectate dilution to the composition of our injectate sample (893 mg/L K). 

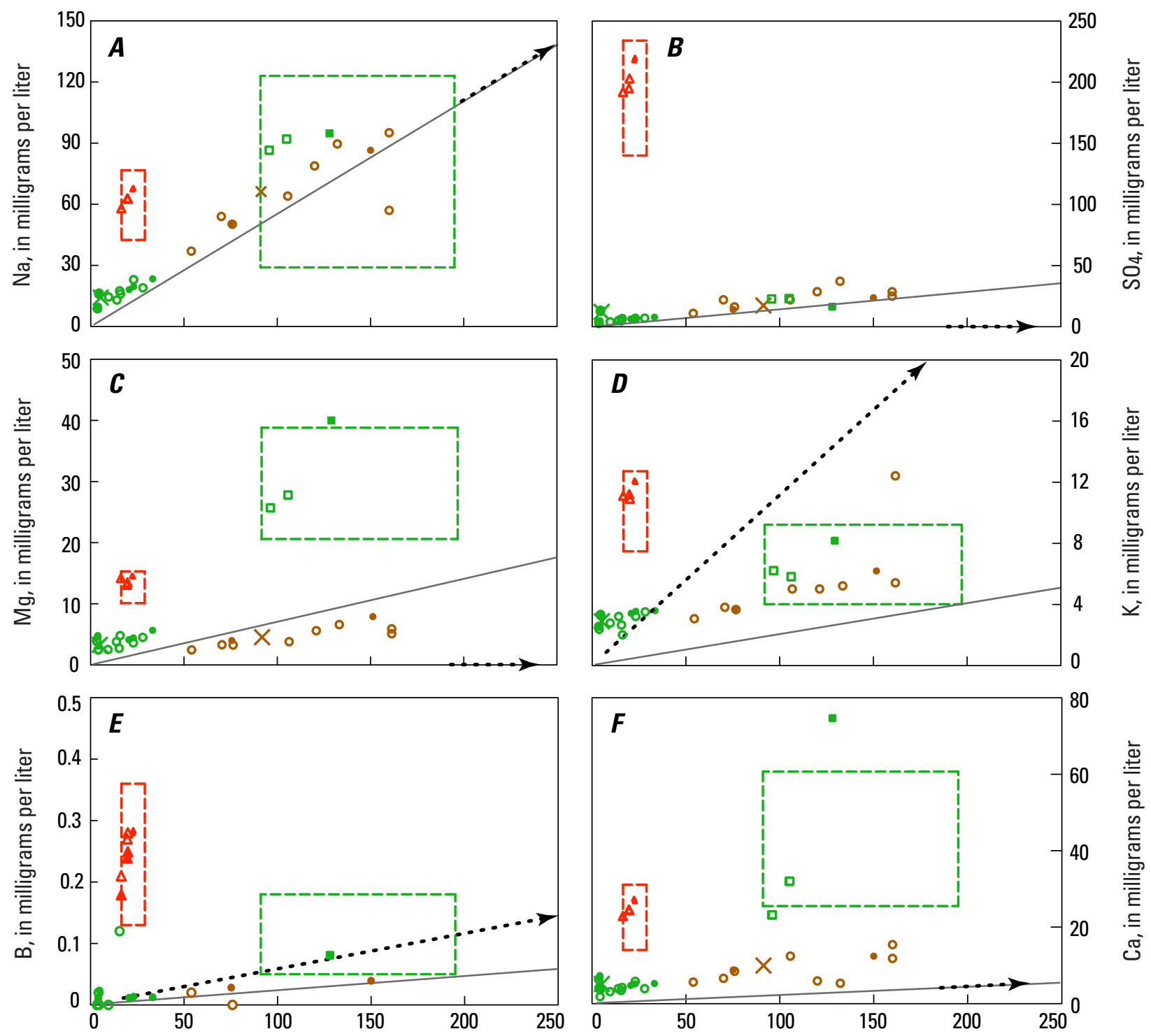

$\mathrm{Cl}$, in milligrams per liter

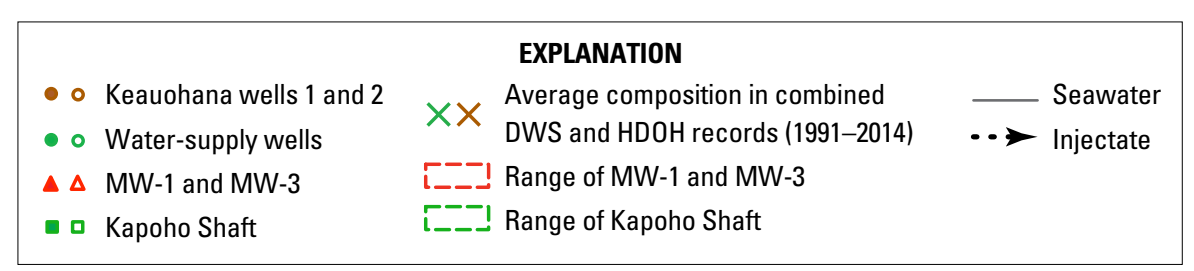

Figure 9. Expanded view of figure 8 highlighting results from particular wells. Filled symbols are data from this study, open symbols from Janik and others (1994). Keauohana wells 1 and 2, brown circles; all other active watersupply wells in table 1, green circles; MW-1 and MW-3, red triangles; Kapoho Shaft, green square. Large X's show average composition in combined County Department of Water Supply and Hawai'i State Department of Health (HDOH) records (1991-2014) for species analyzed at least five times: Keauohana \#1 and \#2, brown; Keonepoko Nui \#1 and \#2, and Pāhoa \#2, green. Range of values for MW-1 and MW-3 from HDOH records during 1991-2014, red boxes; range for Kapoho Shaft from $\mathrm{HDOH}$ records during 1991-94, green boxes. Solid lines extend to the composition of seawater at $19,000 \mathrm{mg} / \mathrm{L} \mathrm{Cl}$; dashed arrows extend to the composition of our injectate sample. 
mineral phases as temperature increases, as does $\mathrm{SO}_{4}$, which can also be reduced to sulfide; $\mathrm{Ca}$ is typically dissolved from minerals at low temperature but can also be soluble at high temperature, depending on reservoir conditions. These contrasting behaviors are clearly reflected in figure 8 . The injectate point lies on the seawater dilution line in the $\mathrm{Na}$ and Ca plots, and thus neither element can be used to distinguish reservoir fluid input from seawater input. The injectate plots above the line in the $\mathrm{K}$ and $\mathrm{B}$ plots, and well below the line and near the $\mathrm{x}$-axis in the $\mathrm{Mg}$ and $\mathrm{SO}_{4}$ plots.

\section{Springs}

The new spring data (fig. 8) extend to slightly higher concentrations than the data of Janik and others (1994). We found the salinity of these ponded springs to vary from point to point within the pool (based on field-measured specific conductance), and the difference in concentration ranges could reflect in part the exact sampling location. Temporal variation in salinity with tidal conditions has also been noted. Janik and others (1994) sampled at low tide, whereas we collected samples at various tidal conditions and made an effort to cover a broad salinity range. Regardless, the overlap in the datasets is large and, most importantly, the new and old data fall on essentially the same trend lines. Thus, the main conditions controlling the chemistry of these springs appear to be unchanged over time.

Janik and others (1994) proposed that the springs contain a component of heated seawater from a source region with a temperature near $165^{\circ} \mathrm{C}$. The actual salinity and temperature of this component are somewhat poorly constrained, because they depend, in part, on large extrapolations of trends like those in figure 8 . Nevertheless, all trend lines radiate from a dilute end-member resembling the well waters toward a saline end-member with thermal characteristics, such as $\mathrm{Mg}$ depletion and $\mathrm{K}$ enrichment, relative to the starting seawater composition. The thermal, saline end-member is thus variably diluted by cold groundwater during underground flow to the springs.

Sorey and Colvard (1994) proposed that the source area for the thermal end-member is near the rift zone in a "conductive halo" around the commercially produced reservoir, where heated seawater can buoyantly rise through the overlying groundwater. They cite geophysical evidence (Kauahikaua, 1993) for outflow of saline thermal groundwater from the rift zone to the coast. Sorey and Colvard (1994) and Janik and others (1994) note that thermal saline water with similar characteristics was encountered in wells between the rift zone and the coast (for example, Malama-Ki and Allison).

None of the spring trend lines deviate far from the seawater dilution lines (fig. 8), but the $\mathrm{Mg}, \mathrm{B}$, and $\mathrm{K}$ trends fall toward the injectate side and could be consistent with a small admixture of reservoir fluid in the thermal, saline endmember. However, best-fit lines through the spring data (new and old) yield different mixing ratios: 17 percent reservoir fluid for $\mathrm{Mg}, 13$ percent for $\mathrm{B}$, and 5.6 percent for K. Furthermore, the $\mathrm{SO}_{4}$ data show no indication of reservoir fluid, nor do the Ca data which, apart from one outlier in the older dataset that is likely spurious, plot on a trend parallel to the seawater and injectate dilution lines. The thermal end-member is apparently richer in $\mathrm{Ca}$ (relative to $\mathrm{Cl}$ ) than both seawater and the PGV reservoir fluid. The major-ion chemistry data are not consistent with significant leakage of reservoir fluid into this large groundwater system. The concept of a conductively heated zone at a temperature above $60^{\circ} \mathrm{C}$, where $\mathrm{Mg}$ depletion typically begins (Seyfried and Bischoff, 1979; Sorey and Colvard, 1994), possibly as hot as $165^{\circ} \mathrm{C}$, is consistent with our data.

Two more points about the springs should be made. Their location within or just above the tidal zone exposes them to direct seawater dilution, which is likely the reason that Janik and others (1994) sampled at low tide. However, trends in the $\mathrm{Mg}$ and $\mathrm{K}$ data actually deviate further from the seawater dilution line with increasing $\mathrm{Cl}$ concentration, so that direct seawater dilution is not apparent in the data. Groundwater flow modeling presented by Imada (1984) and discussed by Sorey and Colvard (1994) implies that abundant rainfall and infiltration in the Puna area would rapidly dilute and erase evidence of geothermal contamination during groundwater flow from the rift toward the coast. However, if the springs do not mix with cold seawater at the coast, their $\mathrm{Cl}$ concentrations indicate that they still contain 10-30 percent of the heated seawater end-member $(\mathrm{Cl} \sim 19,000 \mathrm{mg} / \mathrm{L})$. The corresponding $70-90$ percent dilution by dilute groundwater during flow to the coast would not be so great as to completely erase contaminant signatures caused by leakage of reservoir fluids into the "conductive halo".

\section{Groundwater Wells}

Lower concentration ranges are plotted on figure 9 to focus on the well chemistry. Dilution lines in all plots point to the composition of seawater and injectate, which plot far offscale. The active groundwater supply wells are plotted in two groups that distinguish the Keauohana wells from the other, more dilute wells. The results from our samples follow the same trends as the data of Janik and others (1994) except for a few outliers in the older data that are likely spurious. Monitoring records for several public wells are available from the State $\mathrm{HDOH}$ and (or) the County DWS, and these records fill the gap between our 2014 sampling and the pre1994 data reported by Janik and others (1994). The number of analyses for each well and each species varies greatly; for example, some wells have been analyzed frequently for $\mathrm{Na}$ but never for B. For this study, we combined the records from the Keonepoko Nui and Pāhoa wells and calculated average concentrations for each species of interest (fig. 9). We also combined the records of the two Keauohana wells between 1991 and 2014 and denote the average concentrations on figure 9. Averages were not calculated unless the number of analyses in the combined HDOH and DWS records exceeded five. 
The averages that were calculated plot within the respective groups of well data from our study and that of Janik and others (1994).

For species other than $\mathrm{Mg}$, data trends fall along, or parallel to, the seawater dilution lines. Seawater is thus an important source of dissolved species even in this low concentration range. Additional $\mathrm{Na}, \mathrm{K}, \mathrm{Mg}$, and $\mathrm{Ca}$ can be derived from mineral dissolution in the aquifer, so that the wells generally plot above the seawater dilution lines. The $\mathrm{Mg}$ data for the Keauohana wells follow a trend subparallel to the injectate dilution line. These wells have long been considered to have a slight geothermal character (Iovenitti, 1990; Janik and others, 1994), but the trends in $\mathrm{SO}_{4}, \mathrm{~K}$, and B clearly differ from injectate-dilution trends, and therefore no component of reservoir fluid can be discerned. The geothermal component in the Keauohana wells could be similar to the conductively heated seawater in the coastal springs, slightly depleted in Mg. Regardless, the older data from Janik and others (1994) include samples from the mid-1970s, prior to geothermal development, and the similarity over 40 years argues against any substantial impact on chemistry from PGV operations.

The Kapoho Shaft was originally used as a public-supply well but has not been pumped in decades. The small portable pump we used to bring up water was not capable of fully purging water from the well and bringing in fresh groundwater from the local aquifer. Perhaps as a result of this, our sample differs somewhat from all previous analyses, but shows a general similarity in that it is rich in $\mathrm{Mg}, \mathrm{Ca}$, and $\mathrm{HCO}_{3}$ (table 2; fig. 9). Janik and others (1994) attribute these characteristics to mineral dissolution by dissolved $\mathrm{CO}_{2}$. The $\mathrm{B}$ concentration in this well plots on the injectate-dilution line, but the $\mathrm{Mg}, \mathrm{Ca}$, and $\mathrm{SO}_{4}$ concentrations provide no evidence for influence of PGV injectate.

\section{Thermal Wells}

The new data for MW-1 and MW-3 are compositionally similar to the older data from Janik and others (1994), but slightly higher in several constituents (fig. 9). The data fall within the range observed in $\sim 75$ samples collected from these two adjacent wells between 1991 and 2014 as part of the ongoing $\mathrm{HDOH}$ water monitoring program.

The unique chemistry of the water in these two wells is attributed to absorption of $\mathrm{H}_{2} \mathrm{~S}$ gas from an underlying steam zone, followed by oxidation to sulfuric acid, which dissolves cations from aquifer minerals (Janik and others, 1994; Sorey and Colvard, 1994). Thus, the major anion is sulfate and cations are substantially elevated relative to the seawater dilution line. Steam absorption also explains the high concentrations of B, which becomes volatile at high temperatures. Variations in the relative proportions of rainfall recharge and steam upflow likely cause some of the chemical variability over time but the absence of obvious long-term trends in water composition (fig. 9) suggests that geothermal operations are not inducing major changes to these groundwaters.
Well MW-2, plotted in figure 8, shows a greater seawater influence than MW-1 and MW-3, but also a clear depletion in $\mathrm{Mg}$ and a small enrichment in $\mathrm{SO}_{4}$ relative to the seawater dilution lines. Some small component of $\mathrm{H}_{2} \mathrm{~S}$-laden steam may explain the $\mathrm{SO}_{4}$ enrichment, but this well is also located near the former HGP-A site, where $\mathrm{SO}_{4}$ from gas abatement procedures was allowed to infiltrate during the 1980s (D.M. Thomas, University of Hawaii, Mānoa, personal commun., 2015). The water chemistry is generally consistent with conductively heated seawater diluted by local groundwater. The long-term HDOH monitoring record (fig. 10) shows a high degree of chemical variability at MW-2 that must reflect in part frequent changes in the mixing proportions of the source fluids. The chemistry of our sample is within the range of variability in the monitoring data. This well is equipped with a small gas-lift pump, and the low flow rate we used for sampling probably explains why our sample is several degrees cooler than is typical of the recent monitoring data. Despite this issue, the $\mathrm{HDOH}$ record shows clear long-term trends of declining temperature and increasing $\mathrm{Mg}$ concentration that are independent of source mixing and likely linked, given that $\mathrm{Mg}$ is more easily retained in solution at lower temperatures. These long-term trends may be an indirect impact of geothermal development, in that conductive heat transfer might decline with long-term extraction of heat from the reservoir, but any linkage to geothermal operations is speculative. A possible link between changes in temperature and chemistry in 1991-92, and a steam blowout at well KS-8 was found unconvincing by Sorey and Colvard (1994), and the amplitude of variations in the record since that time (fig. 10) make such a link even less likely.

Other thermal wells exist in the Puna area but are not pumped, and were therefore not suitable for our sampling protocol. Two of these wells, Malama-Ki and TH-3, were included in the $\mathrm{HDOH}$ monitoring program until the year 2000, and the resulting data are shown in figure 11 along with data from Janik and others (1994). These wells, and the thermal Allison well, show a high degree of temporal variability, as seen in the large spread in data in every plot (fig. 11). Nevertheless, apart from a few outlying points, the data do show some clustering and trends.

The trend along the seawater-dilution line is fairly clear for $\mathrm{Na}$ and $\mathrm{Cl}$. In contrast to the coastal springs, the thermal wells show depletion in both $\mathrm{Mg}$ and $\mathrm{SO}_{4}$ relative to seawater dilution lines - a noted characteristic of the injectate. However, the trends through the data miss the injectate and indicate mixing between two source components, dilute local groundwater and seawater that has been extensively hydrothermally altered, greatly reducing its $\mathrm{Mg}$ and $\mathrm{SO}_{4}$ concentrations. A three-component mixture that includes an injectate component could also be consistent with the data. However, the $\mathrm{HDOH}$ monitoring data for Malama-Ki and TH-3 plot on and around the older data from Janik and others (1994), which includes analyses from the 1970s in Kroopnick and others (1978), suggesting that these wells were not changing in response to geothermal operations through the year 2000 . 


\section{Stable Isotopes}

The isotopic composition of groundwaters in the Puna area was investigated in the 1970 s by McMurtry and others (1977). Scholl and others (1996) established an extensive network of precipitation collectors in the region in the early 1990s and found that rainfall on the southern part of the island plotted on a line with formula $\delta \mathrm{D}=8.0 \delta^{18} \mathrm{O}+12$. They defined this formula as the local meteoric water line (LMWL) and noted that it matched the earlier findings of McMurtry and others (1977).

Scholl and others (1995), in their appendix 2, reported isotopic values for many of the springs and wells sampled in our study and averaged the values from 2-3 different samples of each feature with the earlier data from McMurtry and others (1977). In figure 12A, the isotopic data for our 2014 samples is compared with that in appendix 2 of Scholl and others (1995) for wells and springs in the Puna area. The two datasets show an overall similarity despite the fact that some sampling locations differ. However, the new spring data are clearly shifted upward (toward less negative $\delta \mathrm{D}$ values) relative to the older data. The springs puzzlingly plot on or near the LMWL of Scholl and others (1995), even though they contain a component of heated seawater. Closer inspection reveals that the new data from the groundwater wells plot slightly to the left of the LMWL; that is, the change in isotopic composition is not restricted to the springs.

The isotopic composition of precipitation, and hence groundwater, in a given area can shift over time in response to changing climatic conditions. A change in storm tracks or precipitation patterns that persists for some months could conceivably cause a temporary shift in the LMWL in a setting like the Puna area, where recharge and groundwater velocities are high. The 2014 data for supply and monitoring wells adhere to a line with a formula $\delta \mathrm{D}=7.86 \delta^{18} \mathrm{O}+13.2$ (fig. 12B) With our limited number of sampling points, we cannot define a new LMWL, but we take our line of best fit to reasonably characterize Puna groundwater in 2014. Relative to this line, the springs plot in the direction of seawater as expected. Isotope and $\mathrm{Cl}$ data combine (figs. $12 C, D$ ) to
Figure 10. Temperature $\left(\mathrm{T}\right.$ in $\left.{ }^{\circ} \mathrm{C}\right)$ and concentration (in $\mathrm{mg} / \mathrm{L}$ ) of several major species in MW-2 over time based on Hawai'i State Department of Health records (open symbols). Filled symbols show results for our sample of April 30, 2014. A) $\mathrm{Na}$ (blue diamonds), $\mathrm{Cl}$ (green circles); $B$ ) $\mathrm{K}$ (purple diamonds), $\mathrm{Ca}$ (squares), $\mathrm{Mg}$ (triangles), T (red circles).
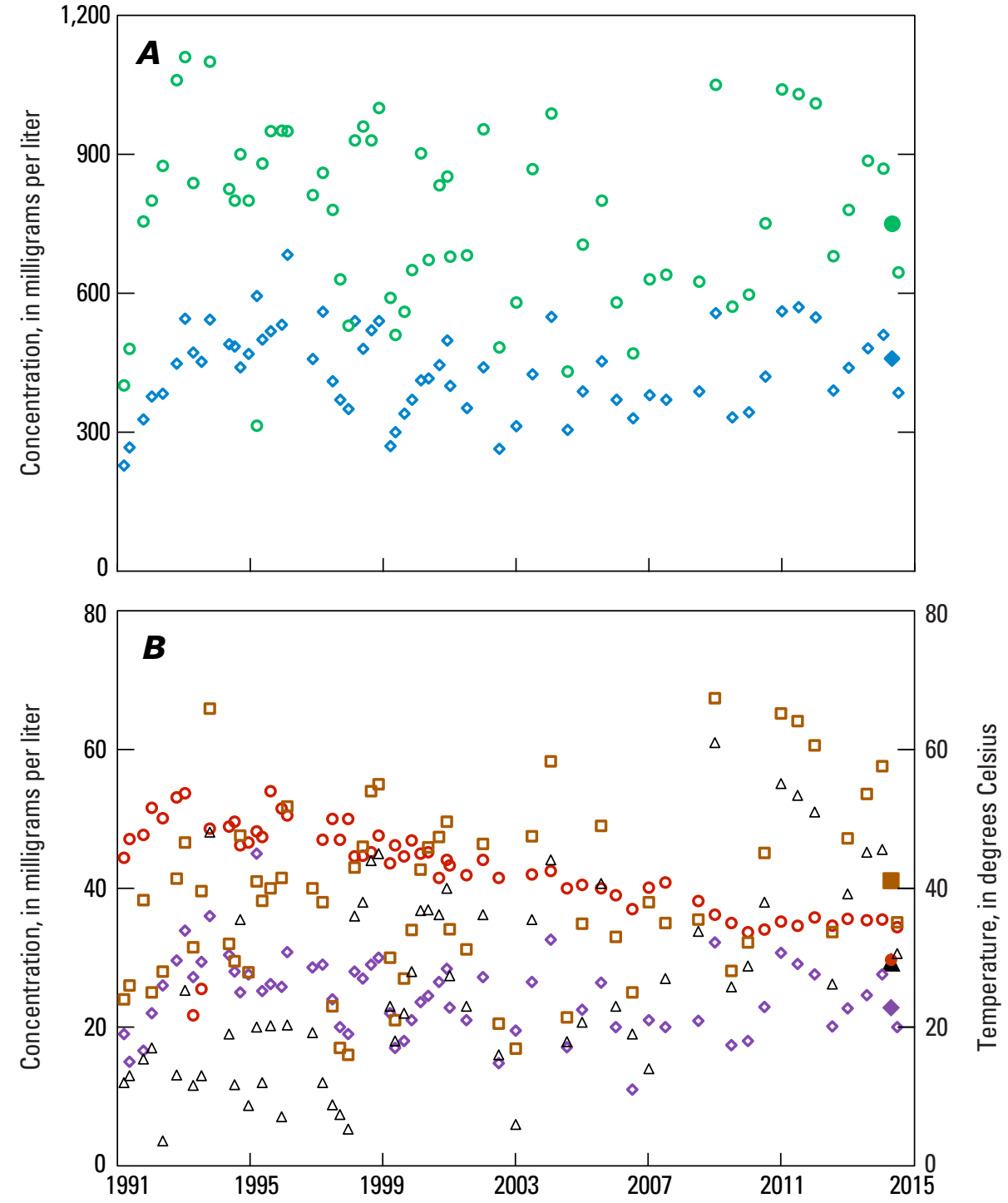

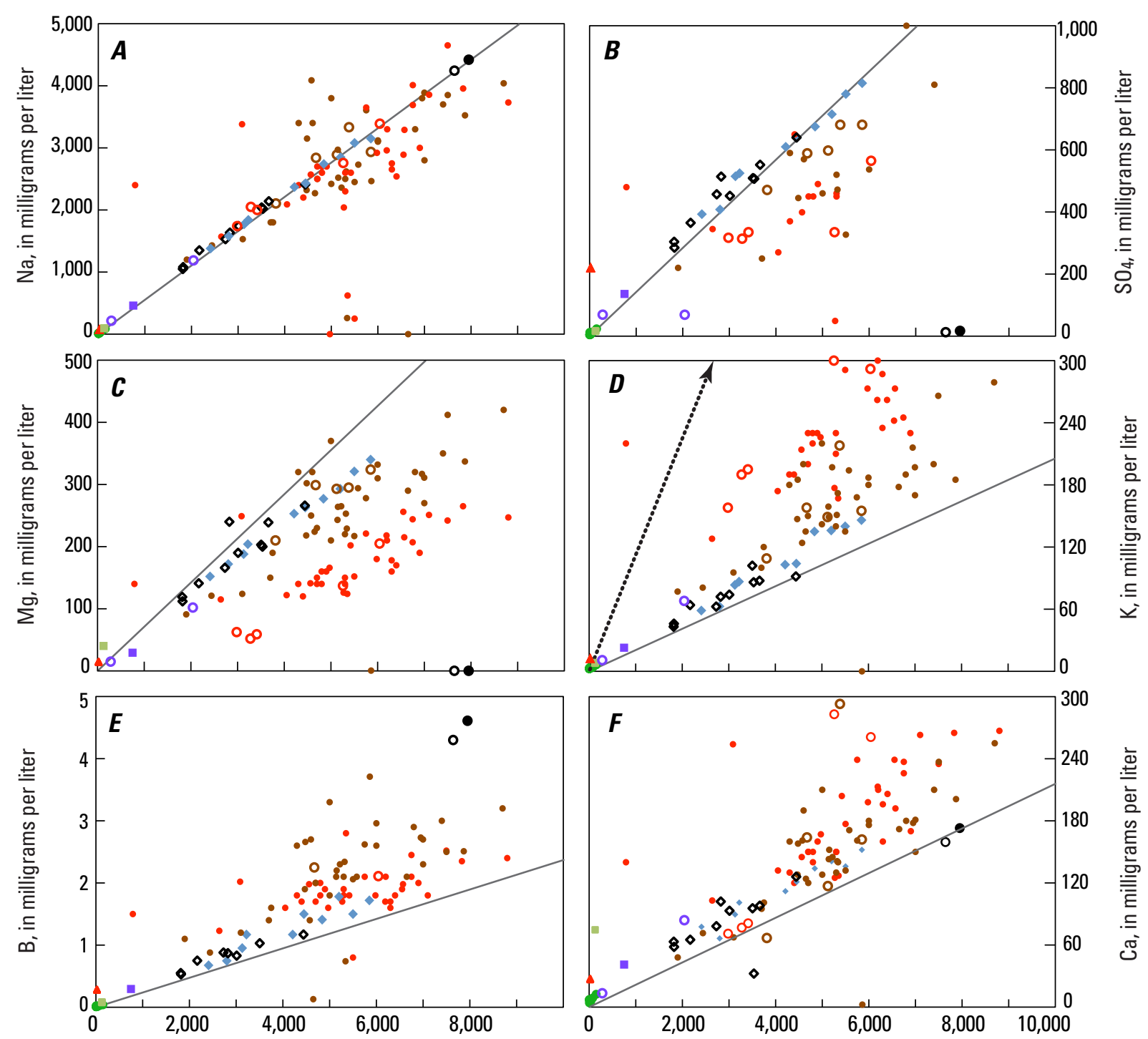

$\mathrm{Cl}$, in milligrams per liter

Figure 11. Data for thermal groundwater wells added to data of figure 8, concentrations of selected chemical species versus $\mathrm{Cl}$ (note changes in scale for some species). TH 3, red circles; Malama-Ki, brown circles; Allison, purple circles. Open symbols from Janik and others (1994); filled symbols from Hawai $i$ State Department of Health records 1991-2000.

\begin{tabular}{|lll|}
\hline \multicolumn{3}{|c|}{ EXPLANATION } \\
- Water-supply wells & $\circ \bullet$ TH3 \\
- Kapoho Shaft & $\circ \bullet$ Malama-Ki \\
AW-1, MW-3 & $\circ$ Allison \\
- MW-2 & $\circ \bullet$ Injectate \\
$\diamond$ Coastal springs & $\ldots$ Injectate dilution \\
& & Seawater dilution \\
&
\end{tabular}



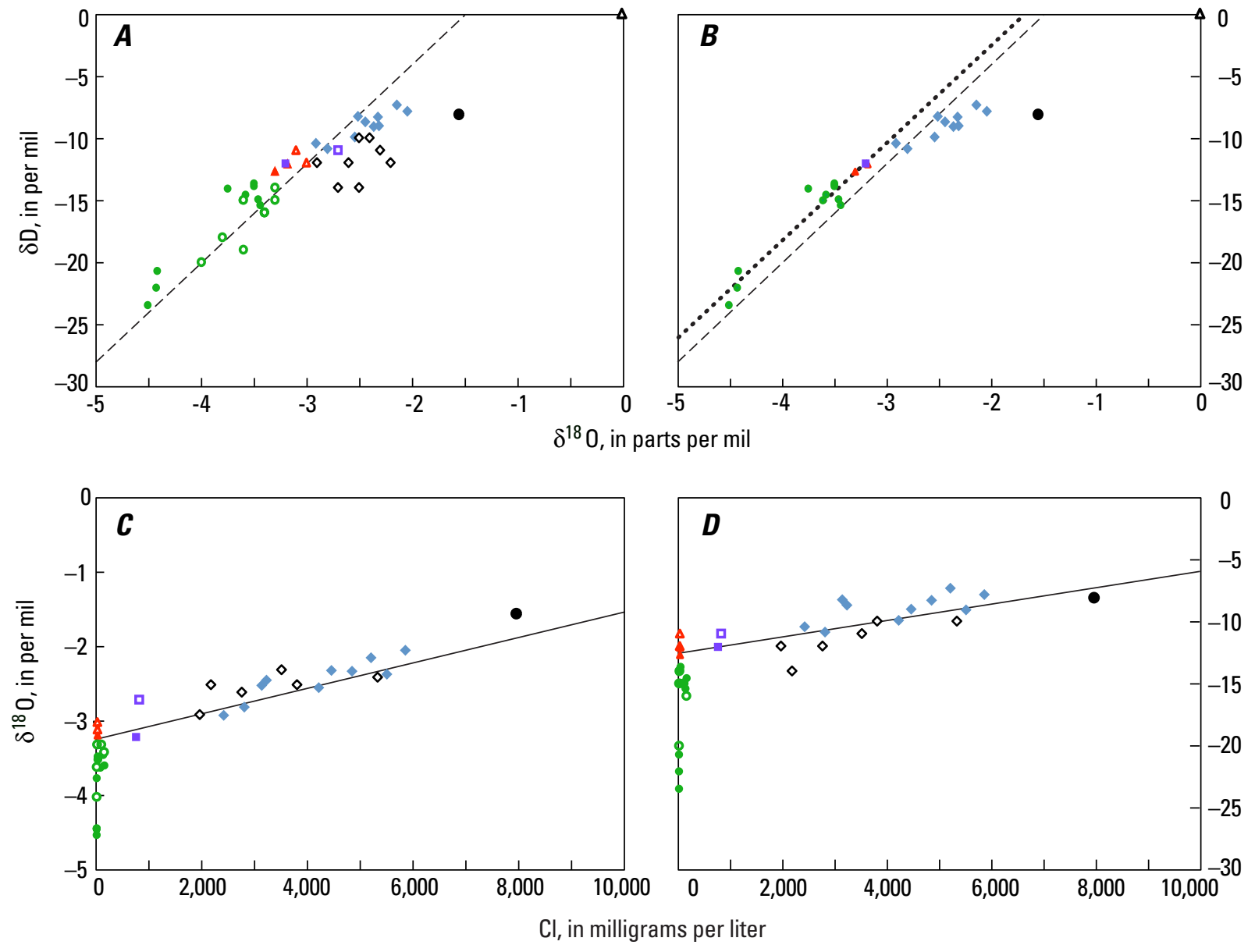

Figure 12. Stable isotope results. Groundwater wells including Kapoho Shaft, green circles; MW-1 and $M W-3$, red triangles; MW-2, purple square; coastal springs, blue and black diamonds; injectate, black EXPLANATION circle. Results from this study are shown as filled symbols; open symbols are data reported in appendix 2 of Scholl and others (1995). Open black triangle represents standard mean ocean water (SMOW). A) $\delta D$ versus $\delta^{18} O$ (in per mil) with local meteoric water line (LMWL) of Scholl and others (1995). B) 2014 results only with regression line for wells (dotted line). C) $\delta^{18} \mathrm{O}$ (in per mil) versus $\mathrm{Cl}$ (in $\mathrm{mg} / \mathrm{L}$ ). $D$ ) $\delta \mathrm{D}$ (in per mil) versus $\mathrm{Cl}$ (in $\mathrm{mg} / \mathrm{L}$ ). Solid black line in $C$ and $D$ extends from the monitoring wells to the composition of seawater at $19,000 \mathrm{mg} / \mathrm{L} \mathrm{Cl}$. 
support the inference that the springs are mixtures of heated seawater and local groundwater. This groundwater appears to be isotopically similar to that in the monitoring wells near PGV. An injectate component would not be recognizable on the basis of stable isotopes.

Some part of the change in the $\delta \mathrm{D}$ values of the springs over time, and the apparent shift to higher average salinity (fig. 12D), could reflect changing conditions at depth (for example, in the conductive halo), which might include boiling and steam formation as hypothesized by Janik and others (1994). However, explanations for the small observed changes, and any linkage to geothermal development, are speculative at this point.

\section{Conclusions}

In response to concerns raised in the report by Adler (2013), our groundwater sampling program focused on water-supply wells and on thermal springs in the coastal environment. We were able to access, sample, and analyze nearly all of our intended targets for pentane and isopropanol, two tracer compounds that enter the fluid at the PGV power plant and are injected into the deep geothermal reservoir. Isopropanol was not detected in any groundwaters. Traces of pentane were detected in one of the PGV monitoring wells (MW-2) and in one sample from Keonepoko Nui well \#2. Replicate samples indicate that the "detect" at Keonepoko Nui is spurious. The pentane in MW-2 could be linked to PGV injectate, but alkane abundances are consistent with a natural source, such as buried organic matter that is degraded at the warm aquifer temperatures. Thus, neither tracer provided meaningful evidence for contamination of groundwater by PGV fluids, although the recent onset of isopropanol use (September 2013) would probably preclude its migration to sites far from the power plant prior to our sampling. Pentane was found to degrade in the hot $\mathrm{H}_{2} \mathrm{~S}$-rich geothermal fluids, and degradation of isopropanol cannot be ruled out. Degradation complicates, but does not exclude, the use of these tracers to detect leakage of reservoir fluids into shallow groundwater. They would certainly be of great value for local detection of direct leakage of injectate into groundwater due to well casing failure, for example.

Previous studies of groundwater chemistry in the Puna area (for example, Sorey and Colvard, 1994; Janik and others, 1994) have invoked conductive heat flow from the geothermal reservoir into saline groundwater that is consequently altered from its original seawater composition. The postulated hot saline groundwater is diluted by shallow groundwater before emerging at the coastal springs or, after great dilution, being pumped from the Keauohana wells. Our new water chemistry data fit this general model.

The Puna area hydrology is characterized by rapid infiltration of rainfall, a thin freshwater lens, and convective instabilities near the rift zone (Thomas, 1987;
Ingebritsen and Scholl, 1993). These and other factors lead to temporal variations in mixing between dilute and saline end-member fluids and are likely responsible for the short-term compositional variability that is a wellknown feature of many Puna groundwaters. This variability complicates the use of water chemistry in assessing geothermal impacts. However, long-term or abnormal changes in chemistry can still be recognized at features with a long history of sampling. For instance, our results reveal higher average salinity and a small but distinct shift in the isotopic composition of the coastal springs from values measured in the 1970s-1990s. We also find a long-term drop in temperature and increase in $\mathrm{Mg}$ at well MW-2. These changes could be due in part to alteration of pressure gradients and heat flow at depth in response to geothermal development, but direct linkage would be hard to substantiate. Apart from these changes, the similarity between our results, the results from mandated monitoring over the previous 20 years, and results from samples from the 1970s-1990s imply that geothermal production has not had a significant impact on groundwater chemistry.

Our sampling protocol was developed for flowing wells or springs that discharge at the land surface. Sample coverage did not include any offshore vents of warm water, which exist in the area, and we point out that contaminant transport from the geothermal reservoir directly to such features could occur on timescales much different from those based on shallow groundwater velocities assumed in this report. We were also unable to sample any of the hot groundwater wells that lack pumps and are down-gradient from PGV. We reviewed the water chemistry data from $\mathrm{HDOH}$ records for samples collected downhole through the year 2000 at Malama-Ki and TH-3. These data do not show obvious evidence of longterm trends related to geothermal production, but do show significant scatter that might obscure such trends. Samples suitable for pentane and isopropanol analysis could be obtained from such wells, but temporary installation of pumps would likely be required.

If any immediate follow-up to our study is desired, we recommend that it focus on the hot groundwater wells, using pumps to completely flush the wellbores, and on offshore vents of warm water, using underwater sampling techniques as necessary. Given that obvious geothermal impacts were not observed in the groundwaters we studied, we suggest only minor changes to the existing onshore monitoring program: (1) the analytical protocol for the Keauohana and Pāhoa public-supply wells near PGV should include isopropanol on at least an annual basis; (2) a sampling program should be established for a representative group of coastal springs to ensure that comprehensive chemical analyses are performed annually or at least every few years (these analyses should include isopropanol and perhaps pentane); (3) isopropanol analyses should be performed on the monitoring wells (MW-1 through MW-3) at least annually, and more frequently if casing pressures in the injection well show any indication of leakage. 


\section{References Cited}

Adler, P.S., 2013, Geothermal public health assessment; findings and recommendations: The Geothermal Public Health Assessment Study Group, final report prepared by Accord Network 3.0, 203 p., accessed November 13, 2014, at http:// www.accord3.com/docs/Report\%20FINAL.pdf.

Bergfeld, D., Lewicki, J.L., Evans, W.C., Hunt, A.G., Revesz, K., and Huebner, M., 2013, Geochemical investigation of the hydrothermal system on Akutan Island, Alaska, July 2012: U.S. Geological Survey Scientific Investigations Report 2013-5231, 20 p.

Bergfeld, D., Lowenstern, J.B., Hunt, A.G., Shanks, W.C.P., III, and Evans, W.C., 2011, Gas and isotope chemistry of thermal features in Yellowstone National Park, Wyoming: U.S. Geological Survey Scientific Investigations Report 2011-5012, 26 p.

Chapoy, A., Haghighi, H., and Tohidi, B., 2008, Development of a Henry's constant correlation and solubility measurements of n-pentane, i-pentane, cyclopentane, n-hexane, and toluene in water: Journal of Chemical Thermodynamics, v. 40 , p. 1030-1037.

Darling, W.G., 1998, Hydrothermal hydrocarbon gases-1, Genesis and geothermometry: Applied Geochemistry, v. 13, p. $815-824$.

Evans, W.C., Banks, N.G., and White, L.D., 1981, Analyses of gas samples from the summit crater, in Lipman, P.W., and Mullineaux, D.R., eds, The 1980 Eruptions of Mount St. Helens, Washington: U.S. Geological Survey Professional Paper 1250, p. 227-231.

Evans, W.C., Sorey, M.L., Cook, A.C., Kennedy, B.M., Shuster, D.L., Colvard, E.L., White, L.D., and Huebner, M.A., 2002, Tracing and quantifying magmatic carbon discharge in cold groundwatersLessons learned from Mammoth Mountain, USA: Journal of Volcanology and Geothermal Research, v. 114, p. 291-312.

Foote, D., 2005, Inventory of anchialine pools in Hawai'i's national parks: U.S. Geological Survey Fact Sheet 20053129, 2 p.

Gingerich, S.B., 1995, The hydrothermal system of the lower East Rift Zone of Kīlauea Volcano-Conceptual and numerical models of energy and solute transport: Mānoa, University of Hawai'i, Ph.D dissertation, 215 p.

Hem, J.D., 1985, Study and interpretation of the chemical characteristics of natural water ( $3 \mathrm{~d}$ ed.): U.S. Geological Survey Water-Supply Paper 2254, 263 p.

Imada, J.A., 1984, Numerical modeling of the groundwater in the east rift zone of Kîlauea Volcano, Hawai'i: Honolulu, University of Hawai'i, M.S. Thesis, 102 p.
Ingebritsen, S.E., and Scholl, M.A., 1993, The hydrogeology of Kīlauea Volcano: Geothermics, v. 22, p. 255-270.

Iovenitti, J.L., 1990, Shallow ground water mapping in the lower East Rift Zone Kīlauea volcano, Hawai' $\mathrm{i}$ : Geothermal Resources Council Transactions, v. 14, p. 699-703.

Janik, C.J., Nathenson, M., and Scholl, M.A., 1994, Chemistry of spring and well waters on Kīlauea Volcano, Hawai' $i$, and vicinity: U.S. Geological Survey Open-File Report 94-586, $166 \mathrm{p}$.

Kauahikaua, J., 1993, Geophysical characteristics of the hydrothermal systems of Kīlauea volcano, Hawai' $i$ : Geothermics, v. 22, p. 271-299.

Kroopnick, P.M., Buddemeier, R.W., Thomas, D., Lau, L.S., and Bills, D., 1978, Hydrology and geochemistry of a Hawaiian geothermal system-HGP-A: Hawai' $i$ Institute of Geophysics, HIG-78-6, 64 p.

McAuliffe, C.D., 1971, GC determination of solutes by multiple phase equilibrium: Chemical Technology, v. 1, p. 46-51.

McMurtry, G.M., Fan, P.F., and Coplen, T.B., 1977, Chemical and isotopic investigations of groundwater in potential geothermal areas in Hawai'i: American Journal of Science, v. 277 , p. $438-458$.

Presser, T.S., and Barnes, I., 1974, Special techniques for determining chemical properties of geothermal water: U.S Geological Survey Water-Resources Investigations Report 74-22, $11 \mathrm{p}$.

Revesz, K., and Coplen, T.B., 2008a, Determination of the delta $\left({ }^{2} \mathrm{H} /{ }^{1} \mathrm{H}\right)$ of water-RSIL lab code 1574 , chap. $\mathrm{C} 1$ of Revesz, K., and Coplen, T.B., eds., Methods of the Reston Stable Isotope Laboratory : U.S. Geological Survey Techniques and Methods 10-C1, 27 p., accessed June 1, 2014, at http://pubs.water.usgs.gov/tm10C1/.

Revesz, K., and Coplen, T.B., 2008b, Determination of the delta $\left({ }^{18} \mathrm{O} /{ }^{16} \mathrm{O}\right)$ of waterRSIL lab code 489 , chap. $\mathrm{C} 2$ of Revesz, K., and Coplen, T.B., eds., Methods of the Reston Stable Isotope Laboratory:U.S. Geological Survey Techniques and Methods, 10-C2, 28 p., accessed June 1, 2014, at http://pubs.water.usgs.gov/tm10C2/.

Scholl, M.A., Ingebritsen, S.E., Janik, C.J., and Kauahikaua, J.P., 1995, An isotope hydrology study of the Kîlauea Volcano area, Hawai'i: U.S. Geological Survey WaterResources Investigations Report 95-4213, 44 p.

Scholl, M.A., Ingebritsen, S.E., Janik, C.J., and Kauahikaua, J.P., 1996, Use of precipitation and groundwater isotopes to interpret regional hydrology on a tropical volcanic islandKîlauea volcano area, Hawai'i: Water Resources Research, v. 32 , p. $3525-3557$. 
Seyfried, W.E., Jr., and Bischoff, J.L., 1979, Low temperature basalt alteration by seawater-An experimental study at $70^{\circ} \mathrm{C}$ and $150^{\circ} \mathrm{C}$ : Geochimica et Cosmochimica Acta, v. 43, p. 1937-1947.

Sorey, M.L., and Colvard, E.M., 1994, Potential effects of the Hawai'i Geothermal Project on ground-water resources on the Island of Hawai'i: U.S. Geological Survey WaterResources Investigations Report 94-4028, 35 p.

Takasaki, K.J., 1993, Occurrence and movement of ground water in Kīlauea Volcano and adjacent areas of Mauna Loa Volcano, Island of Hawai'i: U.S. Geological Survey OpenFile Report 93-82, 28 p.

Tassi, F., Vaselli, O., Capaccioni, B., Montegrossi, G., Barahona, F., and Caprai, A., 2007, Scrubbing process and chemical equilibria controlling the composition of light hydrocarbons in natural gas discharges-An example from the geothermal fields of El Salvador: Geochemistry, Geophysics, Geosystems, v. 8, 22 p. Q05008, doi:10.1029/2006GC001487.

Teplow, W., Marsh, B., Hulen, J., Spielman, P., Kaleikini, M., Fitch, D., and Rickard, W., 2009, Dacite melt at the Puna Geothermal Venture wellfield, Big Island of Hawai' $i$ : Geothermal Resources Council Transactions, v. 33, p. 989-994.
Thomas, D.M., 1987, A geochemical model of the Kîlauea east rift zone, in Decker, R.W., Wright, T.L., and Stauffer, P.H., eds., Volcanism in Hawai'i: U.S. Geological Survey Professional Paper 1350, p. 1507-1525.

Thomas, D.M., 1990, The history and significance of the Hawai'i Geothermal Project: Geothermal Resources Council Transactions, v. 14 , p. $809-814$.

Wilde, F.D., Radtke, D.B., Gibs, J., and Iwatsubo, R.T., eds., 2004, Processing of water samples (version 2.2), in Wilde, F.D., and Radtke, D.B., eds., National field manual for the collection of water-quality data: U.S. Geological Survey Techniques of Water-Resources Investigations, book 9, chap. A5, accessed April 1, 2014, at http://pubs.water.usgs. gov/twri9A5/.

Wilhelm, E., Battino, R., and Wilcock, R.J., 1977, Lowpressure solubility of gases in liquid water: Chemical Reviews, v. 77, p. 219-262.

Xia, X., Ellis, G.S., Ma, Q., and Tang, Y., 2014, Compositional and stable carbon isotopic fractionation during nonautocatalytic thermochemical sulfate reduction by gaseous hydrocarbons: Geochimica et Cosmochimica Acta, v. 139, p. 472-486. 
Produced in the Menlo Park Publishing Service Center

Manuscript approved for publication September 23, 2015

Edited by Katherine D. Jacques

Layout and design by Jeanne S. DiLeo 
ลิ

롤.

㝏

言

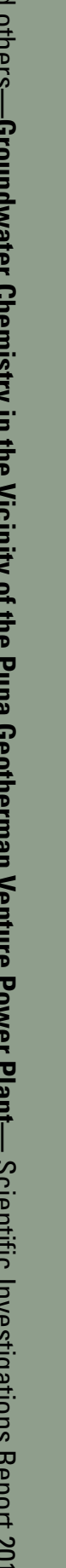

芦

홀 